SC-DR $-67-3003$

Development Report

February 1968

NORMAL AND ABNORMAL ENVIRONMENTS

EXPERIENCED BY CARGO ON A

FLATBED TRUCK

J. T. Foley, 1541

Sandia Laboratory, Albuquerque 
Issued by Sandia Corporation,

a prime contractor to the

United States Atomic Energy Commission

\section{LEGAL NOTICE}

This report was prepared as an account of Government sponsored work Neither the United States, nor the Commission, nor any person acting on behalf of the Commission:

A. Makes any warranty or representation, expressed or implied, with respect to the accuracy, completeness, or usefulness of the information contained in this report, or that the use of any information, apparatus, method, or process disclosed in this report may not infringe privately owned rights; or

B. Assumes any llablitities with respect to the use of, or for damages resulting from the use of any Information, apparatus, method, or process disclosed in this report,

As used in the above, "person acting on behals of the Commisston" includes any employee or contractor of the Commission, or employee of such contractor. to the extent that such employee or contractor of the Commission or employee of such contractor prepares, disseminates, or provides access to, any information pursuant to his employment or contract with the Commission, or his employment with such contractor. 


\section{DISCLAIMER}

This report was prepared as an account of work sponsored by an agency of the United States Government. Neither the United States Government nor any agency Thereof, nor any of their employees, makes any warranty, express or implied, or assumes any legal liability or responsibility for the accuracy, completeness, or usefulness of any information, apparatus, product, or process disclosed, or represents that its use would not infringe privately owned rights. Reference herein to any specific commercial product, process, or service by trade name, trademark, manufacturer, or otherwise does not necessarily constitute or imply its endorsement, recommendation, or favoring by the United States Government or any agency thereof. The views and opinions of authors expressed herein do not necessarily state or reflect those of the United States Government or any agency thereof. 


\section{DISCLAIMER}

Portions of this document may be illegible in electronic image products. Images are produced from the best available original document. 
SC-DR - 67-3003

\title{
NORMAL AND ABNORMAL ENVIRONMENTS EXPERIENCED BY CARGO ON A FLATBED TRUCK
}

J. T. Foley, 1541

Sandia Laborabory, Albuquerque

February 1968

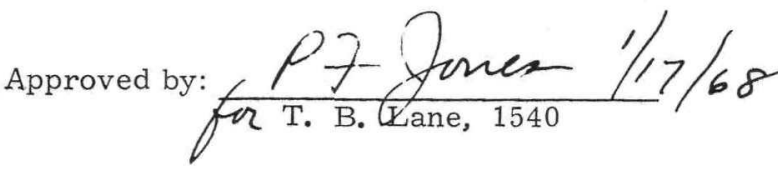

\begin{abstract}
The Environmental Data Analysis (EDA) group at Sandia Corporation was invited by Beech Aircraft personnel to accompany them on an over-the-road test of a flatbed truck. Environmental measurements obtained by the EDA gruup are presented.
\end{abstract}

\section{LEGAL NOTICE}

This report was prepared as an account of Government sponsored work. Neither the United States, nor the Commission, nor any person acting on behalf of the Commission:

A. Makes any warranty or representation, expressed or implied, with respect to the accuracy, completeness, or usefulness of the information contained in this report, or that the use of any information, apparatus, method, or process disclosed in this report may not infringe privately owned rights; or

B. Assumes any liabilities with respect to the use of, or for damages resulting from the ef any information, apparatus, method, or process disclosed in this report.

As used in the above, "person acting on behalf of the Commission" includes any em ployee or contractor of the Commission, or employee of such contractor, to the extent that ployee or contractor of the Commission, or employee of such contractor, to the extent that such employee or contractor of the Commission, or employee of such contractor prepares, disseminates, or provides access to, any information pursuant to his employment or contract
with the Commission, or his employment with such contractor. 
$$
\text { . }
$$ 
TABLE OF CONTENTS

\begin{tabular}{lr} 
& \multicolumn{1}{c}{ Page } \\
Introduction & 5 \\
Background & 5 \\
Test Procedures & 6 \\
Data Reduction & 10 \\
Data Analyses & 10 \\
$\quad$ Normal Environments & 10 \\
$\quad$ Long-Duration Phenomena & 10 \\
$\quad$ Transient Phenomena & 10 \\
$\quad$ Abnormal Environments & 11 \\
$\quad$ Long-Duration Phenomena & 11 \\
$\quad$ Transient Phenomena & 11 \\
Ronclusions & 13 \\
List of References & 14 \\
Appendix A - Normal Conditions & 15 \\
Appendix B - Abnormal Conditions & 17
\end{tabular}

LIST OF ILLUSTRATIONS

\section{Figure}

1. Truck Used in Tests

6

2. Load in Truck Tests

6

3. Beech Instrumentation

7

4. ELI 31 Sampler on Truck Bed

7

5. Pickup Location on Truck Bed to Rear of Load

7

6. Loading Dock and Railroad Track Employed in Tests

9

7. Dirt Road and Desert Brush in Area Where Tests Were Conducted

9

8. Typical Cattle Guard Over Which Environments Were Sampled 


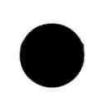

i)

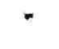




\section{NORMAL AND ABNORMAL ENVIRONMENTS EXPERIENCED BY CARGO ON A FLATBED TRUCK}

Introduction

This report categorizes and presents the data samples taken at the input-to-cargo interface by Sandia during Beech Aircraft truck tests. The potential effects of these environments on general cargo are discussed. Data presented in this report will be placed in the Sandia Corporation Environmental Data Bank.

\section{Background}

Beech Aircraft Corporation, Boulder, Colorado, was engaged in determining the dynamic environment experienced by a Dewar flask during shipment of the flask from Amarillo, Texas, to White Sands Proving Ground, New Mexico.

During its search for background data on truck transport dynamic environment, Beech learned of the existence of the Sandia Corporation Environmental Data Bank through a paper on Preliminary Analysis of Truck Transport Environment presented at a DOD Shock and Vibration Symposium. ${ }^{1}$

Mr. H. R. Williamson, Chief of Engineering-Testing at Beech, visited the EDA group at Sandia and, during his visits to the Sandia Environmental Data Bank to obtain descriptive data concerning the dynamic environment experienced by cargo in over-the-road transport, saw the ELI 31 portable environmental sampler.

Since Beech was planning an over-the-road evaluation of the environment experienced by its Dewar flask mount, Mr. Williamson invited us to accompany Beech personnel on the test and to take our recorder and sample the environments experienced during their tests. We felt this would be an opportunity to extend our data on truck transport environmental phenomena for the Sandia Corporation Environmental Data Bank. $^{2}$

In return for this invitation, the EDA group furnished Beech with magnetic tape dubs of the data taken with our recorder. 
Truck: The truck used in the tests was a flatbed Ford F600, Beech A/C No. C. 99 (Figure 1).

Load: The load on the truck consisted of a distributed mass-model of a Beech liquid helium Dewar flask which was, in turn, mounted on an isolated (mitigating) pallet (Figure 2).

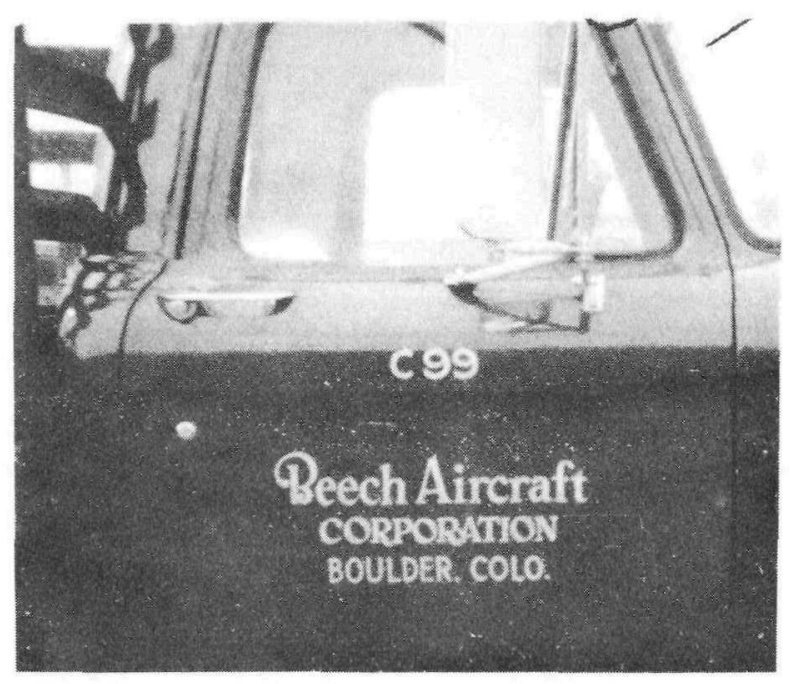

Figure 1. Truck Used in Tests
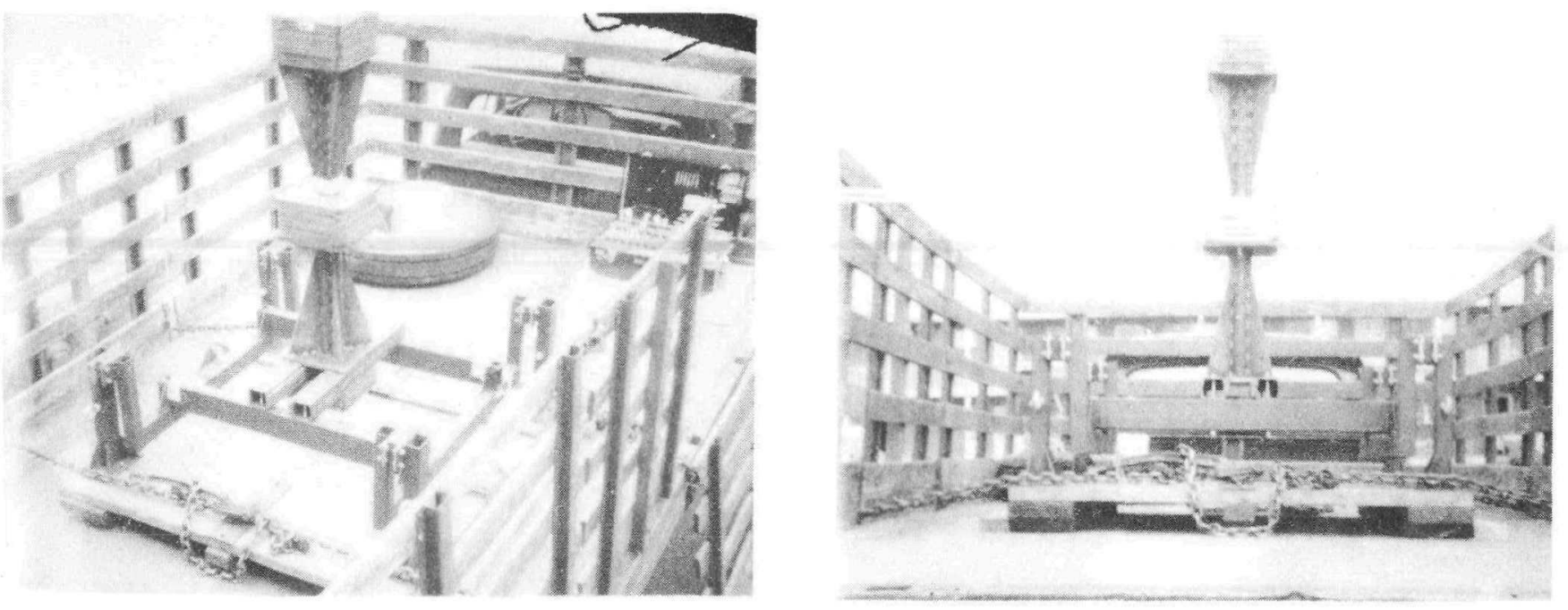

Figure 2. Load in Truck Tests 
Beech instrumentation used was the shock level trigger type located at the flask/pallet interface (Figure 3).

Sandia instrumentation used by EDA personnel was the ELI 31 portable environmental sampler used in conjunction with piezoelectric transducers (Figure 4). The Sandia transducers were located ahead of and behind the truck/load interface on main members of the truck bed (Figure 5).

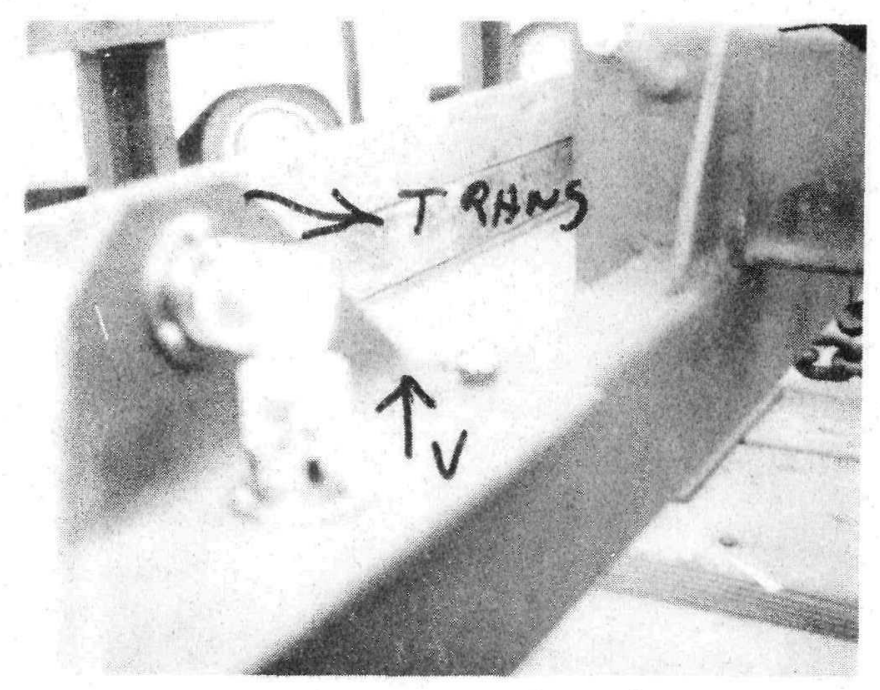

Figure 3. Beech Instrumentation

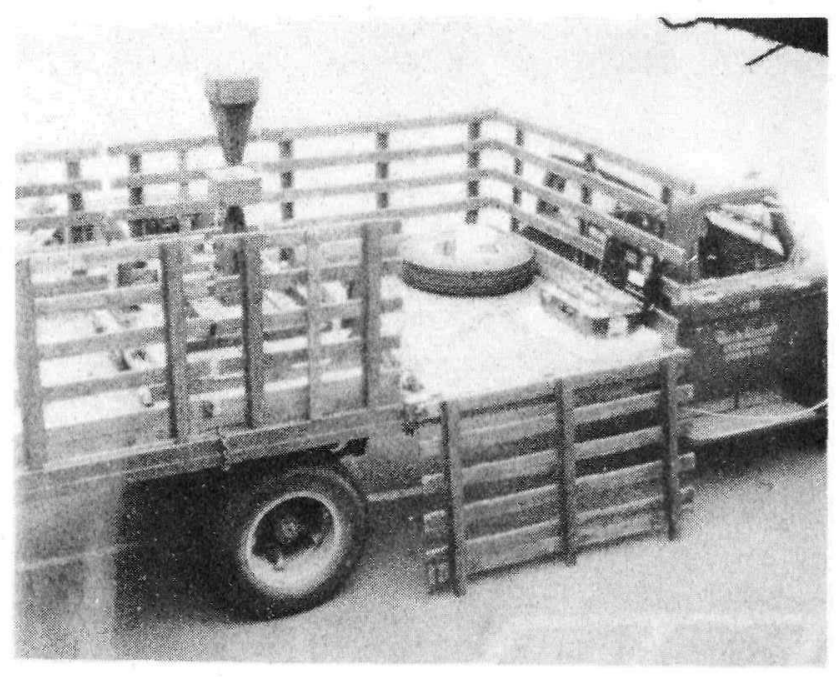

Figure 4. ELI 31 Sampler on Truck Bed

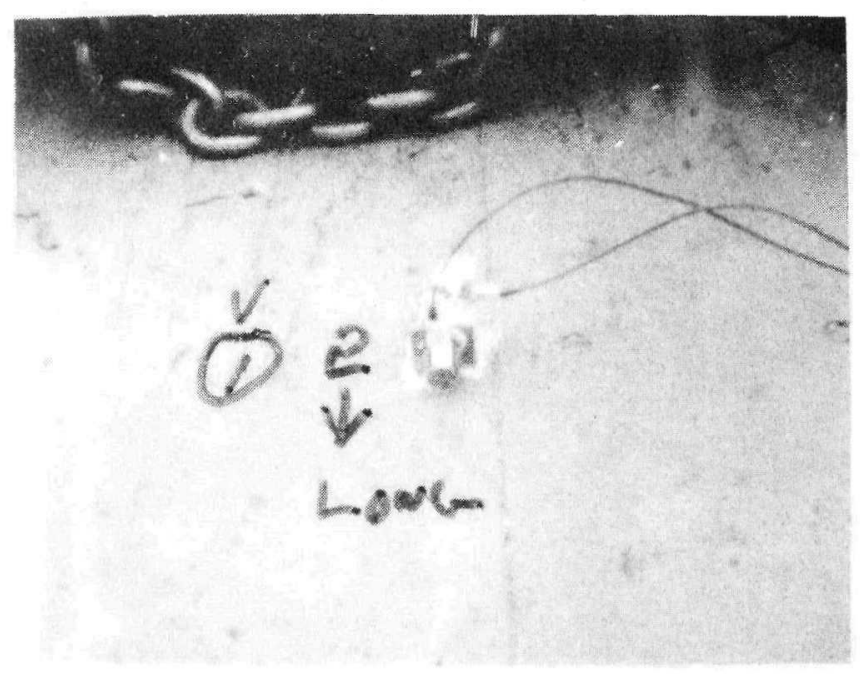

Figure 5. Pickup Location on Truck Bed to Rear of Load 
Since there were seven additional channels available on the ELI 31 recorder, we donated these channels to Beech A/C personnel for locating pickups on the Dewar mount and on their distributed mass model as they desired. Table I lists all pickup locations and associated instrumentation information.

TABLE I

Truck Test Instrumentation Directory

Test Dates:

$1 / 23-24,1967$

\begin{tabular}{|c|c|c|c|c|c|c|}
\hline \multirow{2}{*}{$\begin{array}{l}\text { Ch } \\
\text { No. } \\
\end{array}$} & \multirow{2}{*}{$\begin{array}{l}\text { Pickup } \\
\text { Mod No. } \\
\text { (Endevco) } \\
\end{array}$} & \multicolumn{4}{|c|}{$\begin{array}{c}\text { Calibrate Values or } \\
(\mathrm{g})\end{array}$} & \multirow[b]{2}{*}{ Location in Test } \\
\hline & & $\mathrm{S} / \mathrm{N}$ & 1 & 2 & 3 & \\
\hline 1 & $2213 \mathrm{E}$ & NB78 & $0-2$ & $0-4$ & $0-8$ & V - Truck bed, aft of pallet \\
\hline 2 & $2213 \mathrm{E}$ & NB79 & $0-2$ & $0-4$ & $0-8$ & L - Truck bed, aft of pallet \\
\hline 3 & $2213 \mathrm{E}$ & NB81 & $0-2$ & $0-4$ & $0-8$ & V - Truck bed, fwd of pallet \\
\hline 4 & $2213 \mathrm{E}$ & NB83 & $0-2$ & $0-4$ & $0-8$ & L - Truck bed, fwd of pallet \\
\hline 5 & $2213 \mathrm{E}$ & NB85 & $0-2$ & $0-4$ & $0-8$ & $T$ - Truck bed, fwd of pallet \\
\hline 6 & $2213 \mathrm{E}$ & NB86 & $0-2$ & $0-4$ & $0-8$ & L - Left rear, Dewar mount \\
\hline 7 & 2235 & DC45 & $0-4.4$ & $0-8.7$ & $0-18$ & V - Left rear, Dewar mount \\
\hline 8 & 2235 & $\mathrm{DC} 46$ & $0-4.1$ & $0-8.2$ & $0-17$ & $\mathrm{~T}$ - Right front, Dewar mount \\
\hline 9 & 2235 & CB65 & $0-4.3$ & $0-8.6$ & $0-18$ & V - Right front, Dewar mount \\
\hline 10 & 2235 & CB66 & $0-4.0$ & $0-8.0$ & $0-16.8$ & L - Top of Dewar dummy \\
\hline 11 & 2235 & CB68 & $0-4.0$ & $0-8.0$ & $0-16.8$ & $\mathrm{~T}$ - Top of Dewar dummy \\
\hline 12 & 2235 & FB96 & $0-4.2$ & -- & -- & V - Top of Dewar dummy \\
\hline 13 & -- & -- & -- & -- & -- & $480 \mathrm{cps}$ servo time base \\
\hline 14 & -- & -- & -- & -- & -- & Voice channel \\
\hline Notes: & \multicolumn{4}{|c|}{$\begin{array}{l}\text { 1. Calibrate values given here } \\
\text { are exact settings. } \\
\text { 2. Cal is } 50 \mathrm{cps} \text { square wave } \\
\text { with base at zero. }\end{array}$} & \multicolumn{2}{|c|}{$\begin{array}{l}\text { 3. Base of square wave is zero. } \\
\text { 4. } \mathrm{V}=\text { vertical axis } \\
\text { 5. } \mathrm{L}=\text { longitudinal axis } \\
\text { 6. } \mathrm{T}=\text { transverse axis }\end{array}$} \\
\hline
\end{tabular}

Sandia Instruments: ELI 31 recorder system

Dictaphone

Citizen's band transceivers

The following Beech personnel conducted the tests: H. R. Williamson, Chief, Engineering Testing; R. L. Greeno, Test Engineer, Environmental Group; and C. L. Baese, Project Engineer, LM Conditioning Unit. The author operated the ELI 31 recorder.

The general test procedure was to drive over the route chosen by Beech, isolate certain conditions which might produce unique dynamic environments, and sample the events. The route started at the Lindey Liquid Helium Plant in Amarillo, Texas, and continued west to the Texas/New Mexico border on U. S. 66. Events sampled along this route as being normal environments experienced were as follows:

1. Backing up to loading dock across RR tracks (Figure 6). (Vibran)

2. Driving to weighing station over a series of RR tracks. (Vibran and Spectra)

3. Going into a dip at $15 \mathrm{mph}$. (Vibran)

4. Driving from a low, level road to a raised road. (Vibran)

5. Driving onto bad overpass at 50-55 mph. (Vibran)

6. Driving on heavily patched asphalt highway at $50 \mathrm{mph}$. (Vibran)

7. Driving on access road parallel to interstate highway. (Vibran)

8. Driving on smooth blacktop, 4-lane interstate highway at 50, 55, and $35 \mathrm{mph}$. (Vibran)

9. Driving in paved construction zone at 45 and $55 \mathrm{mph}$. (Vibran)

10. Driving on rough blacktop at $60 \mathrm{mph}$. (Vibran) 


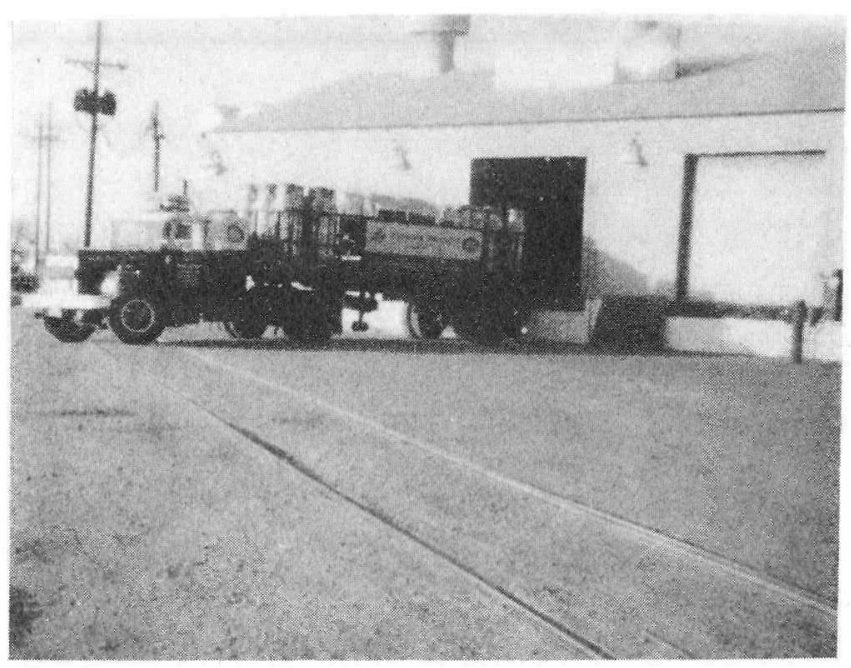

Figure 6. Loading Dock and Railroad Track Employed in Tests

Samples taken in a second series were of unusual situations which might occur along the route and which could produce severe environmental inputs. These were as follows:

1. Colliding with loading dock. (Spectra)

2. Driving over $R R$ tracks at high speed, 45 and $50 \mathrm{mph}$. (Spectra)

3. Driving with two wheels on shoulder at $45 \mathrm{mph}$. (Vibran)

4. Driving completely on shoulder at $45 \mathrm{mph}$. (Vibran)

5. Driving off road in desert brush (Figure 7). (Vibran)

6. Driving into a dip at $50 \mathrm{mph}$. (Vibran)

7. Driving on median of interstate highway (turning around). (Vibran)

8. Hitting potholes in a truck stop at 45-50 mph. (Spectra)

9. Driving on dirt road at $45 \mathrm{mph}$. (Vibran)

10. Running over a cattle guard at $45 \mathrm{mph}$ (Figure 8)。 (Spectra)

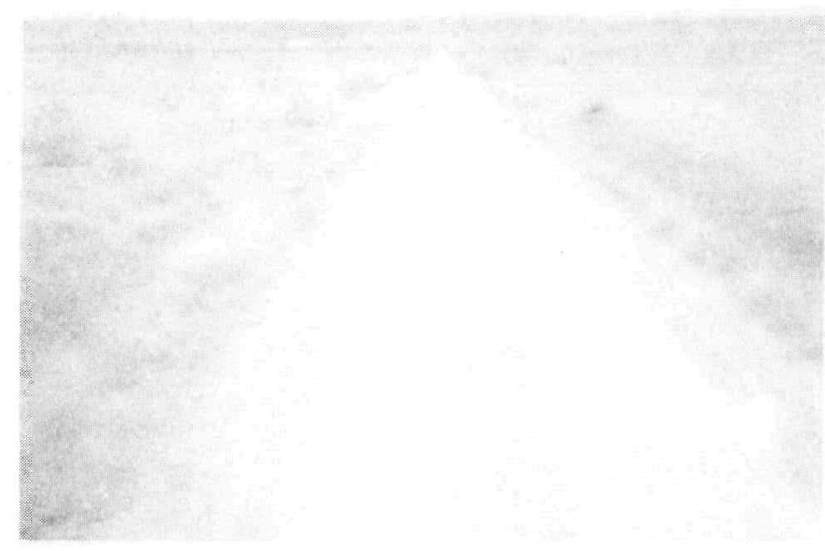

Figure 7. Dirt Road and Desert Brush in Area Where Tests Were Conducted

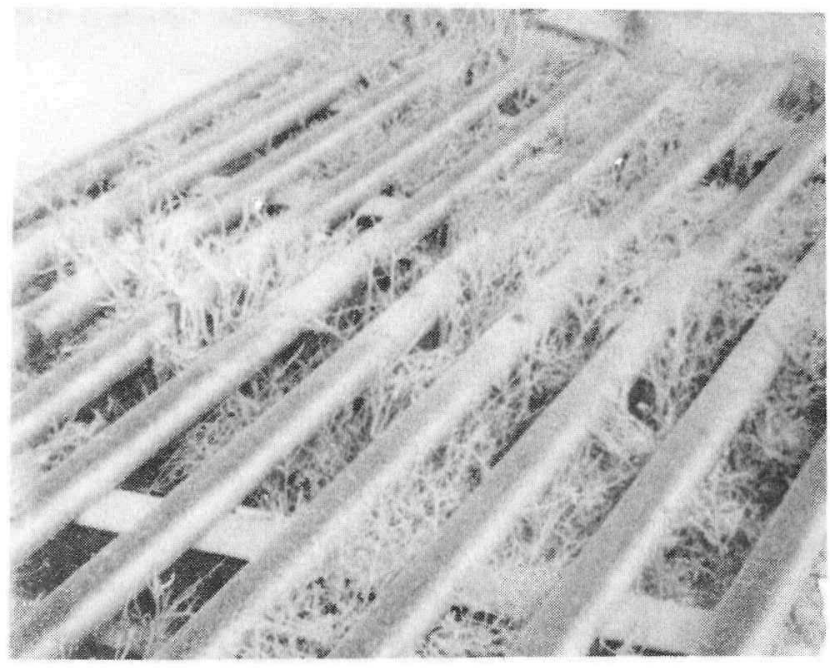

Figure 8. Typical Cattle Guard Over Which Environments Were Sampled 
Data Reduction

The descriptive terms, Vibran and/or Spectra, indicate the data reduction format selected to portray the event. Descriptions of the manner in which these reductions are accomplished, as well as examples of the standard formats, are contained in Sandia Corporation Engineering Manual Procedure S-49, paragraphs 2. 3, 2.5, and 2.6, and Figures A-7, A-8, A-9, and A-10.

Technical descriptions of the data reduction systems are contained in References 3 and 4.

The data reduction was performed by Division 7335 as a part of test request No. T-12317. Computer time required for this reduction was 8 hours and 13 minutes.

Data Analyses

\section{Normal Environments}

Long-Duration Phenomena -- Program Vidar was utilized to analyze the Vibran data reductions obtained from the normal environments of long duration. The following functions were performed:

1. The vertical axis was selected as being the axis in which maximum acceleration levels were detected.

2. The Vibran data from the two truck-bed vertical pickup locations were combined into a composite acceleration density description of the dynamic environment for each of the normal events sampled. Tables A-I through A-X in Appendix A present the resultant description of each of the ten events measured.

3. The tabulation of frequency of occurrence of road types presented in Table II of Reference 2 was used as a guide to obtain weighting factors for each of the ten events. These weighting factors were then applied in the production of a composite acceleration probability density description of the environment produced in the vertical axis at the truck/load interface. Table A-XI gives the resultant acceleration probability description of a trip, in which these ten road types would be encountered. Table A-XII lists the weighting factors that were applied to each road type when generating the composite environment description.

Transient Phenomena -- One normal event, considered to be sufficiently transient to warrant analysis in terms of shock spectra, was the crossing of railroad tracks at slow speed. Figure A-1 of Appendix A presents the vertical g-time history of this event; Figure A-2 presents the resultant shock spectra produced, assuming that the responding single-degree-of-freedom systems had critical damping ratios of $0,0.03$, and 0.10 .

In general, we interpret spectra presentations of transient truck transport environments taken at the payload/truckbed interface in the following manner:

1. Shock spectra picture the response severity on cargo systems.

2. The 0.03 damping spectrum is an estimate of the response severity produced on nonisolated cargo systems. 
3. The 0.10 damping spectrum is an estimate of the response severity produced on isolated or mitigated cargo systems.

4. The 0.0 spectrum is an estimate of the upper limit of response severity which may be achieved in the first application of a series of pulses of the type from which spectra were obtained regardless of the damping which may be present in the system.

5. Cargo responses greater than those predicted for 0.0 damping indicate that it is questionable as to whether the system under consideration approximates a single-degree-of-freedom system.

The shock spectra shown in Figure A-2 are those derived for the pickup location at the rear location on the truck bed. These spectra envelop the spectra obtained at the forward location on the truck bed and are, therefore, considered to represent the greatest vertical axis response severity relative to location of cargo on the truck bed.

\section{Abnormal Environments}

Long-Duration Phenomena -- The following events were considered to occur over a period of time which precluded their interpretation as transient phenomena:

1. Driving with two wheels on shoulder at $45 \mathrm{mph}$.

2. Driving completely on shoulder at $45 \mathrm{mph}$.

3. Driving off the road in desert brush.

4. Driving into a dip at $50 \mathrm{mph}$.

5. Turning around on the median of a 4-lane highway.

6. Driving on a dirt road at $45 \mathrm{mph}$.

Program Vidar was utilized to analyze these events in the following manner:

1. Vidar reductions of the vertical axis pickup locations were combined to provide a description of the "input to load environment" for each event. Tables B-I through B-VI provide these analyses.

2. A probability description was derived of the environment that would be experienced if all these events occurred in a trip where each event was considered equally likely to occur. Table B-VII provides this description.

Transient Phenomena -- Four events in the abnormal category evaluated as transient phenomena were (1) collision with loading docks, (2) crossing railroad tracks at high speed, (3) crossing a cattle guard at high and low speeds, and (4) hitting pot holes at high speed.

\section{Collision With Loading Dock}

Collision with a loading dock has a characteristic which separates this event from other truck transport phenomena evaluated in these tests. The longitudinal, not the vertical, axis produces the greatest response severity. Figure B-1 shows the g-time history of this event, and Figure B-2 shows the derived shock spectra from a truck bed location.

An additional data reduction, Figure B-3, is taken from the test data obtained in this event to illustrate an "applicability test" of shock spectra. The mitigating pallet/load system on the truck was known to have a natural frequency of the order of $10 \mathrm{cps}$. The shock spectrum of Figure B-2 for 0.10 damping indicates that the peak response of a 10-cps single-degree-offreedom system should be of the order of $1.5 \mathrm{~g}$. Figure B-3 is the actual g-time history of 
the longitudinal response of the mitigating pallet load, measured during the test event. The measured system peak response was $\approx 1.5 \mathrm{~g}$, indicating that the assumption that this pallet system approximates a single degree of freedom with 0.10 damping is reasonable.

Figures B-4 and B-5 are g-time histories and shock spectra, respectively, taken at the second longitudinal pickup location on the truck bed during the test. These are included to illustrate that there appears to be little, if any, effect of truck bed location on the resultant longitudinal shock.

Figures B-6 and B-7 are included for the sake of completeness to describe the resulting vertical axis environment produced by this collision event. Only the rearward location time history and spectra are shown, since, in the case of vertical axis environment, the rearward location produced the greater response severity.

\section{Crossing Railroad Tracks at High Speeds (45-50 mph)}

Figures B-8 and B-9 show the g-time history and spectra obtained at a speed of $45 \mathrm{mph}$. Figures B-10 and B-11 present data taken at $50 \mathrm{mph}$ to illustrate that small high-speed variations appear to have little effect on the response severity. As in other environmental events of this nature, shocks at aft location on the truck bed are the most severe, and the vertical axis is, again, the "governing" axis.

Response severity during high-speed crossings of railroad tracks, however, may not be consistent for all possible cargo systems. A comparison with shock spectra obtained when crossing tracks slowly from a stop (Figures A-1 and A-2) indicates that low-speed crossings may have a greater response severity for low natural-frequency cargo systems and that highspeed crossings have a greater response severity for high natural-frequency cargo systems.

The g-time histories of railroad crossings (Figures B- 8 and B-10) indicate that the characteristic environment is one of repetitive shock. For this reason, it would appear that the initial environment would best be represented by the 0 damping spectrum, followed in turn by either the 0.03 or 0.10 damping spectrum, depending upon whether a mitigated or nonmitigated cargo system is being evaluated.

\section{Crossing a Cattle Guard at High and Low Speeds}

Figures B-12, B-13, B-14, and B-15 present the g-time histories and spectra obtained during cattle-guard crossings from the rearward (vertical) truck-bed location. Both the time histories and spectra indicate a remarkable similarity to railroad crossings. As a result of the comparison, our present interpretation is that this environment is not unique and that its potential effects on cargo are the same as those effects produced in crossing railroad tracks.

4. Hitting Pot Holes at High Speed

The pot holes encountered in this test were in the unpaved parking area of a truck stop. They consisted of depressions caused by truck wheels standing when the surface was wet, wheel spin, and ruts formed under the same conditions, as well as ridged ground irregularities produced by general wind and water action. Access to this area was directly off the main paved highway and transition was very abrupt. For a considerable distance leading to this 
area, the paved highway was very smooth blacktop, straight and level, with a posted 60-mph speed limit. This situation made it possible for a vehicle to approach this truck stop at a high rate of speed and turn into this abrupt collection of irregularities with little or no reduction in its highway velocity. A nominal velocity of $45 \mathrm{mph}$ was chosen for sampling this event.

It may be of interest to note that this was the only abnormal environment sampled in which a qualitative experience in relation to the material on the truck bed was noted. During this event, the ELI 31 recording system (weight, 90 pounds), which was resting on a foam plastic pad, separated from the pad and came to rest on the truck floor, moving a distance of about 3 feet in the plane of the truck bed. Vertical height traversed by the recorder was estimated to be of the order of 2 to 4 inches. This vertical travel estimate was inferred from passenger response in the truck cab.

Figures B-16 and B-17 present the g-time history and spectra obtained during this event. Again, the vertical axis and the aft location on the truck bed produced the governing severity of response.

A comparison of response severity for this event with all other events sampled in these tests indicates that pot holes and bumps are potentially the most severe transient vertical environment that cargo will encounter in truck transport.

\section{Conclusions}

Data sampling performed during these tests appears to have accomplished the following:

1. Our data bank store of environmental descriptions of the dynamic inputs to cargo during normal over-the-road operations was extended to include data in the 2-ton truck category.

2. Certain near-accident events were measured which, to our knowledge, have not been previously described in quantitative terms which relate to potential effects on cargo.

3. Our analysis of transient phenomena has led us to postulating a ranking of these transient phenomena in terms of response severity. The results indicate that pot holes or bumps produce the most severe vertical axis environment, and collisions with objects such as loading docks produce the most severe longitudinal environment.

4. Speed appears to produce differing response severity on cargo; low speeds have greater effect on low natural-frequency cargo, high speeds have greater effect on high natural-frequency cargo.

5. Some events are not unique in the dynamic sense, as exemplified by the remarkable similarity of environment encountered on railroad tracks and cattle guards.

6. Location of cargo on the truck bed has an effect on the severity of vertical inputs to cargo, with cargo located over or near the rear wheels getting the roughest ride.

7. Location of cargo on the truck bed appears to have little, if any, effect on longitudinal shocks that may be imposed on the cargo. 
8. Certain "unusual" events were sampled which permitted us to extend our store of environmental descriptions of dynamic inputs to cargo experienced during off-road operations,

9. Except for off-road operation in bumpy terrain, it appears that long-duration phenomena encountered in normal situations is more severe than the long-duration phenomena encountered in what we considered to be unusual events in this test.

\section{Recommendations}

The data obtained in these investigations consist exclusively of acceleration amplitudes. For maximum use in data interpretation and application, it is recommended that apparent weight measurements be obtained, using either the actual truck upon which these acceleration measurements were obtained, or a similar truck of the same load rating and configuration. Of particular interest in this respect would be apparent weight measurements in the 0-to-10-cps region (Reference 5). 
1. Foley, J. T., Preliminary Analysis of Data Obtained in the Joint Army/AEC/Sandia Test of Truck Transport Environment, paper presented February 1966 and published in Part 5 of Shock and Vibration Bulletin \#35, pp. 57-70.

2. Foley, J. T., An Environmental Research Study, paper presented at 1967 IES Symposium, April 1967, published in IES 1967 Proceedings, pp. 363-373.

3. Murfin, W. B., Automated Digital Shock Data Reduction System, paper presented in February 1967 and published in Part 6, Shock and Vibration Bulletin, \#36, pp. 21-36.

4. Department 7180, Vibration Analysis for Weapon Development Test Programs, Sandia Corporation report, SC-DR-321-61, April 1962.

5. Foley, J. T., The Environment Experienced by Cargo on a Flat Bed Tractor-Trailer Combination, SC-RR-66-677, December 1966. 
○. 
APPENDIX A

NORMAL CONDITIONS 
TABLE A-I

Normal Conditions

(Vertical axis, forward and aft locations)

Backing Up to Loading Dock Across Railroad Tracks

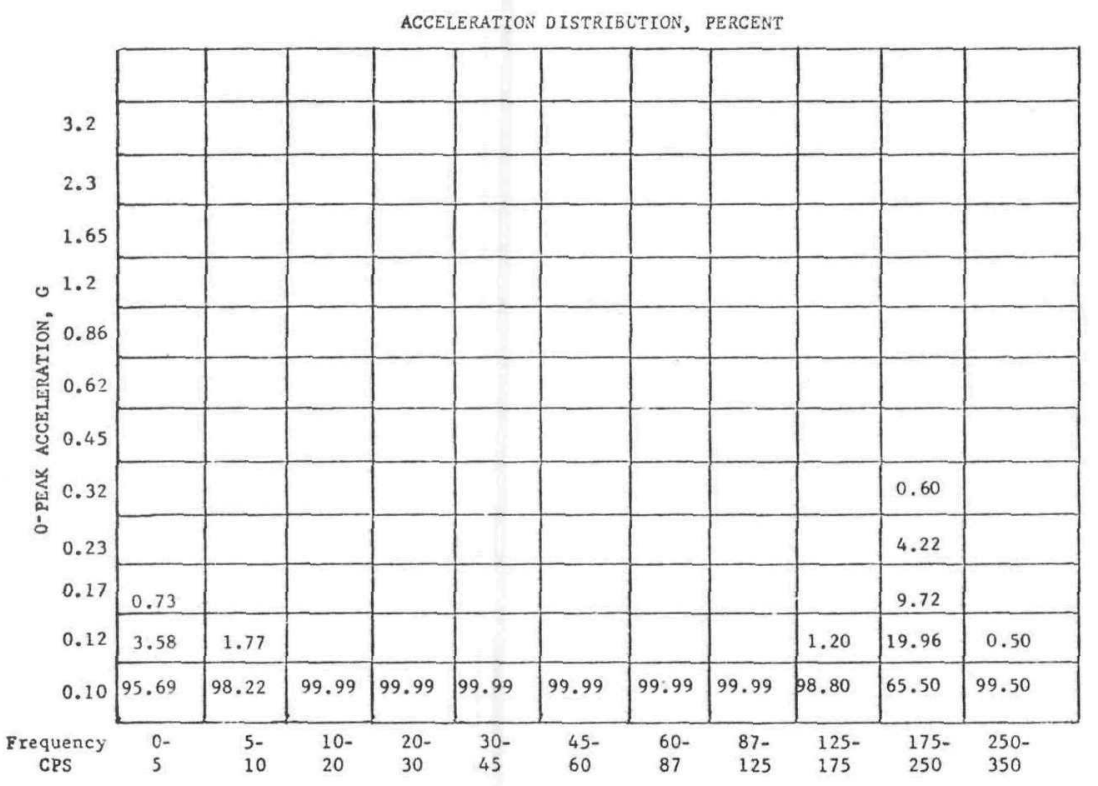

No. of Peaks 139 $\begin{array}{llllll}83 & 1171 & 1650 & 2528 & 3345 & 4568\end{array}$ Total No. of Peaks counted: 15,523
Driving Away From Dock Onto Pavement

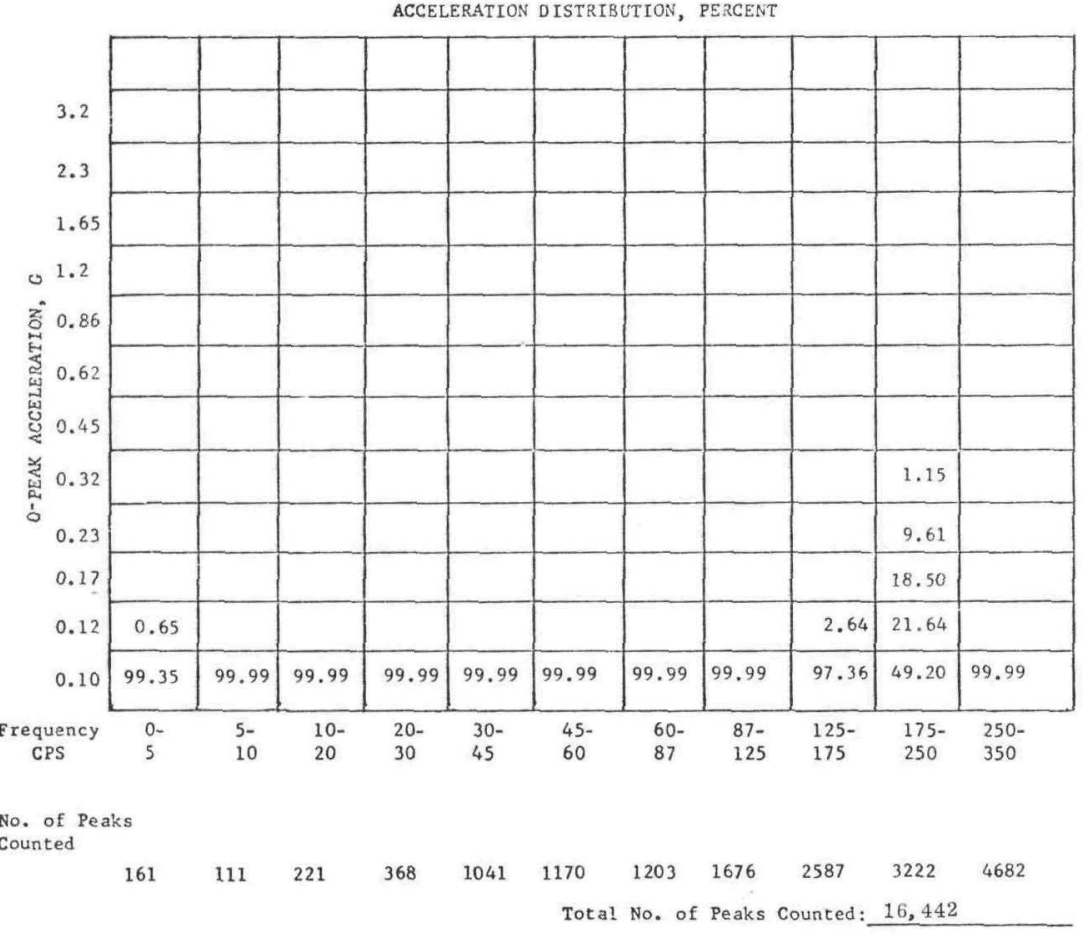


TABLE A-II

Normal Conditions

(Vertical axis, forward and aft locations)

Driving to Weighing Station Over First Set of Railroad Tracks AGCELERATION DISTRIBUTION, PERCENT

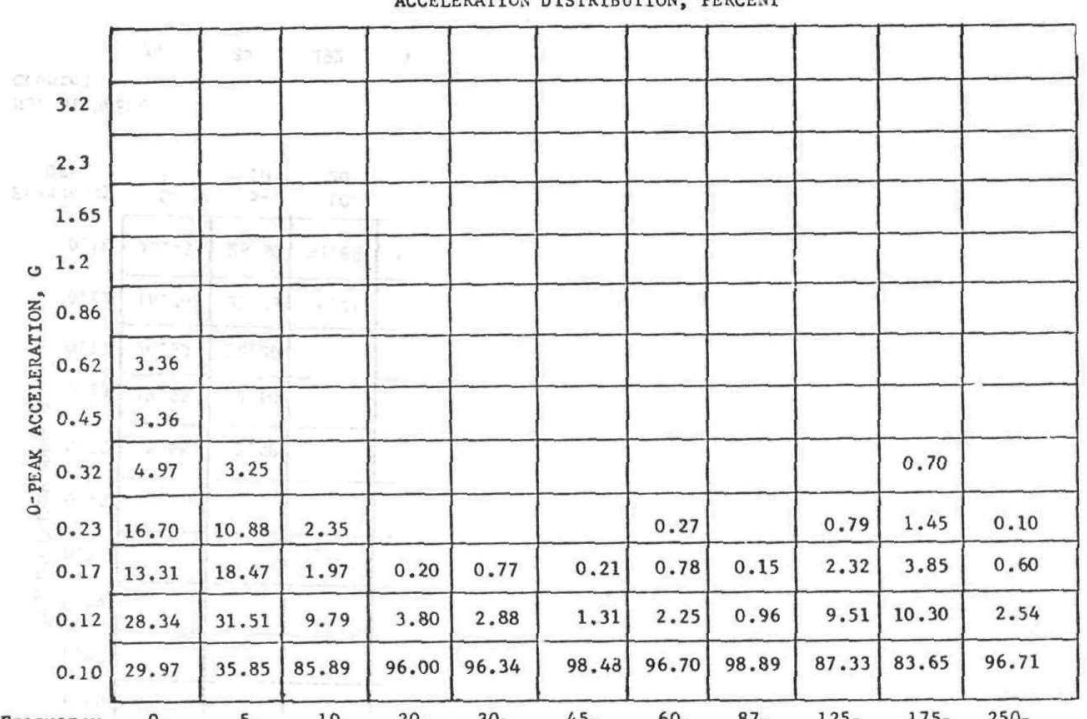

$\begin{array}{clllllllllll}\begin{array}{c}\text { Frequency } \\ \text { CPS }\end{array} & 0- & 5- & 10- & 20- & 30- & 45- & 60- & 87- & 125- & 175- & 250- \\ & 10 & 20 & 30 & 45 & 60 & 87 & 125 & 175 & 250 & 350\end{array}$

No. of Peaks

counted

$\begin{array}{lllllllllll}60 & 92 & 255 & 474 & 1278 & 1509 & 1441 & 2285 & 2737 & 3506 & 4935\end{array}$

Total No. of Peaks Counted: 18,572
Driving to Weighing Station Over Second Set of Railroad Tracks acceleration distribution, percent

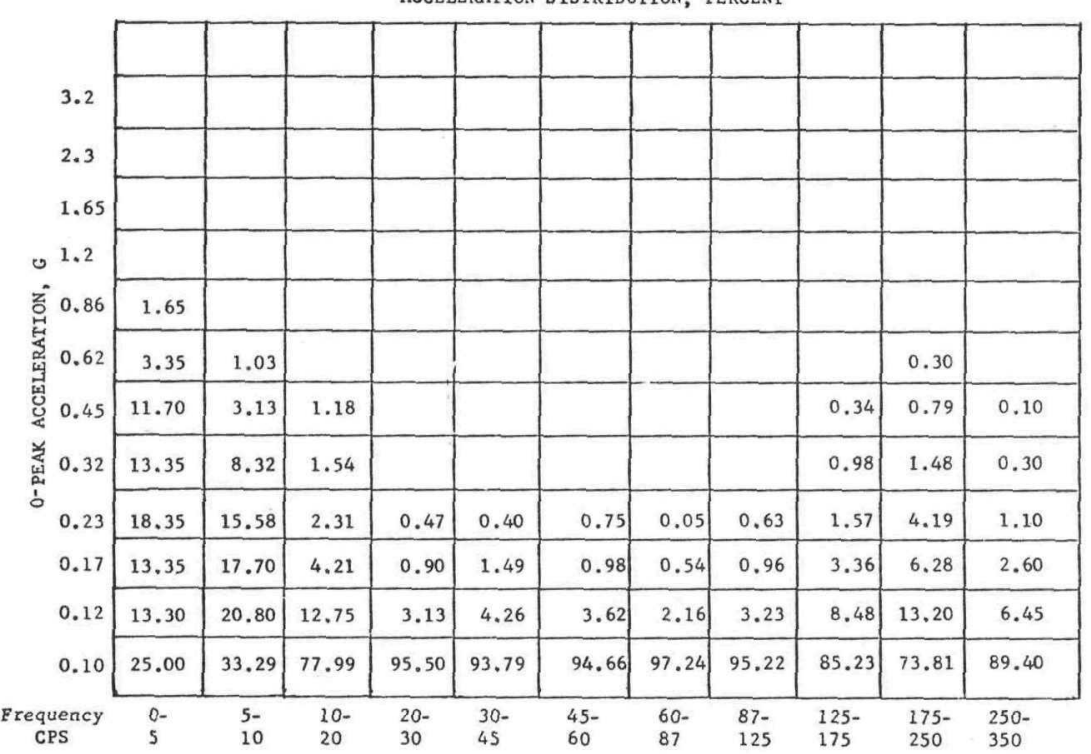

No. of Peaks

Counted

$\begin{array}{lllll}60 & 96 & 259 & 444 & 1048\end{array}$
$1338 \quad 1574 \quad 2151 \quad 2907 \quad 3565 \quad 4918$

Total No, of Peaks counted: 18,360 
TABLE A-III

Normal Conditions

(Vertical axis, forward and aft locations)

Going Into a Dip at Low Speed

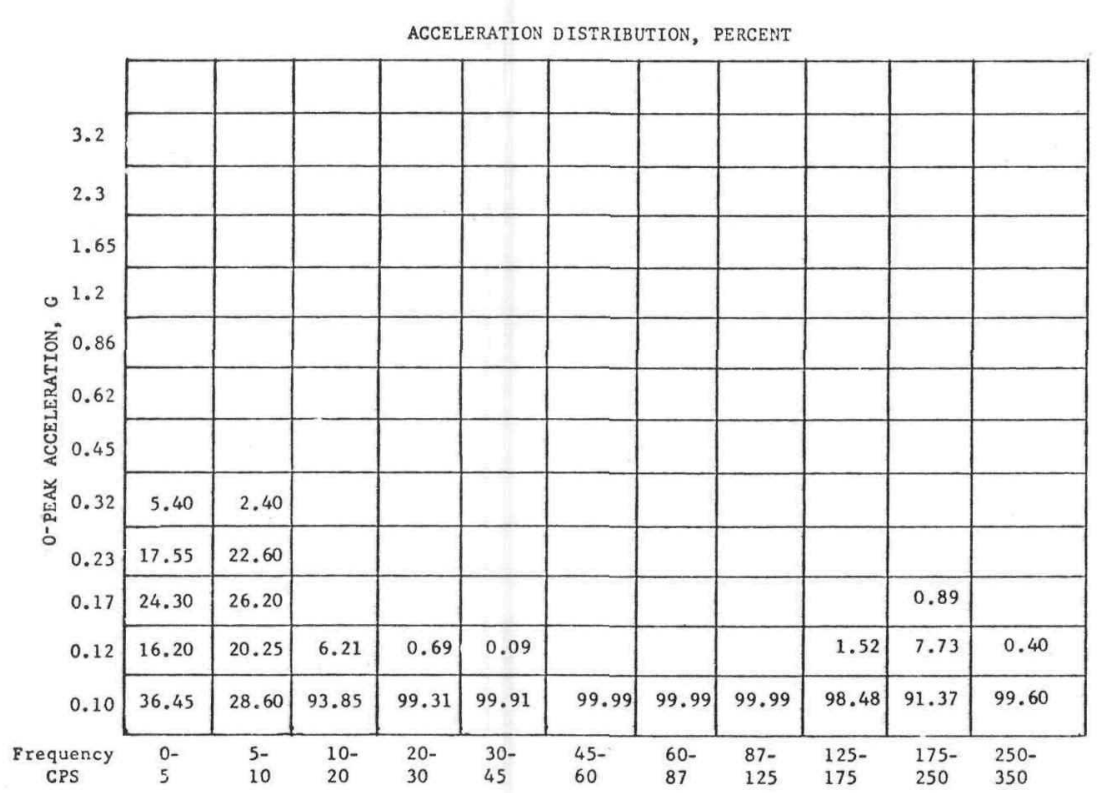

No. of Peaks

Counted

$\begin{array}{lllllllllll}74 & 84 & 292 & 431 & 1227 & 1555 & 1819 & 2379 & 3063 & 3485 & 5311\end{array}$

Total No. of Peaks Counted: 19,720

\section{TABLE A-IV}

Normal Conditions

(Vertical axis, forward and aft locations)

Driving From Low, Level Road to Raised Road

ACCELERATION DISTRIBUTION, PERCENT

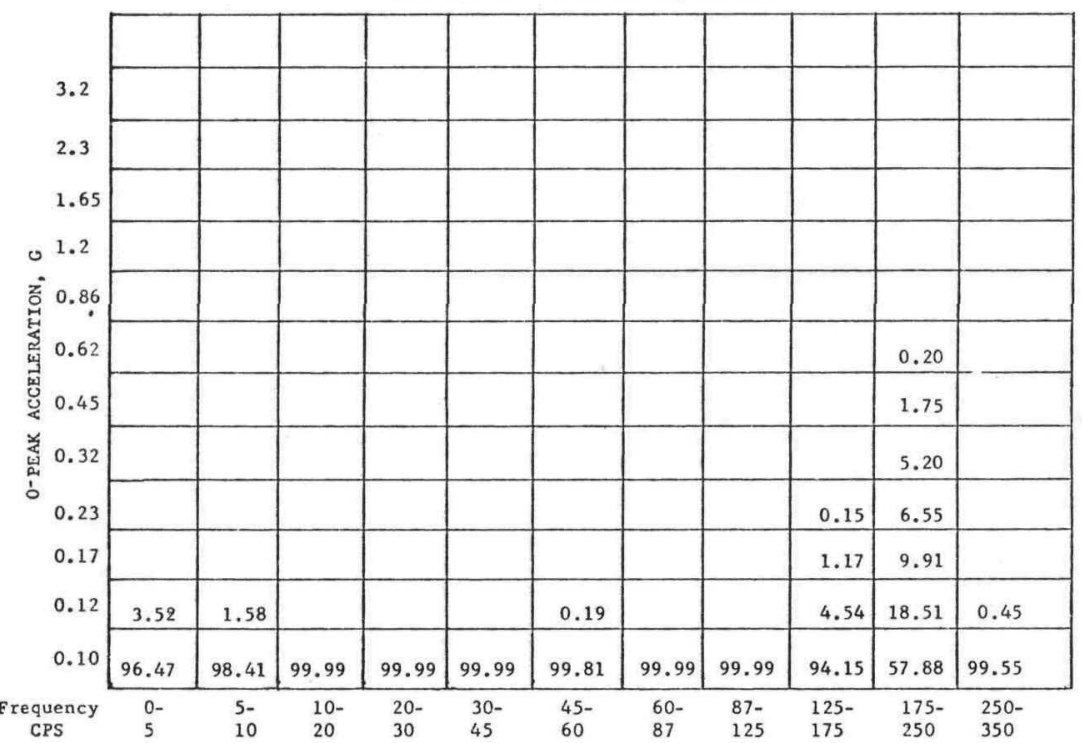

$\begin{array}{clllllllllll}\text { Frequency } & 0- & 5- & 10- & 20- & 30- & 45- & 60- & 87- & 125- & 175- & 250- \\ \text { CPS } & 5 & 10 & 20 & 30 & 45 & 60 & 87 & 125 & 175 & 250 & 350\end{array}$

No. of Peaks

Counted

114 
TABLE A-V

Normal Conditions

(Vertical axis, forward and aft locations)

Driving Onto Overpass at 50-55 mph

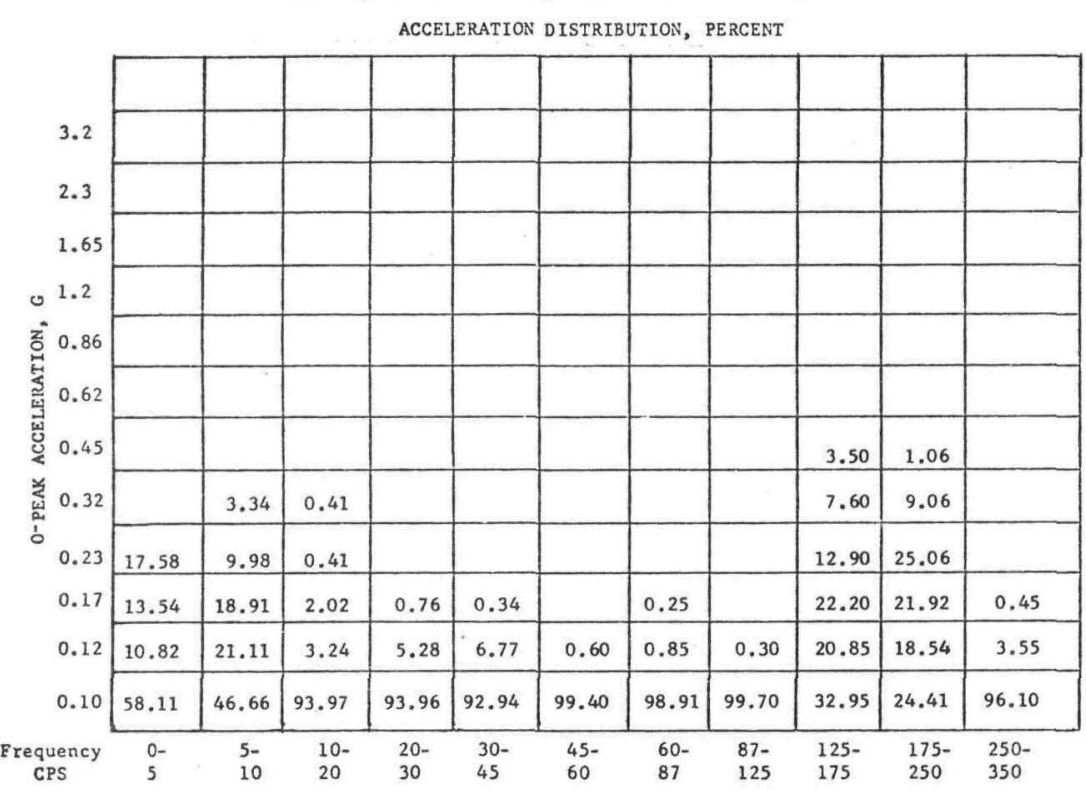

No. of Peaks

74
$90 \quad 248$
$248 \quad 39$
$98 \quad 635 \quad 809$ $\begin{array}{llllll}809 & 1257 & 1643 & 2625 & 3247 & 4748\end{array}$

Total No. of Peaks Counted: 15, 376
Driving Off Overpass at 50-55 $\mathrm{mph}$ ACCELERATION DISTRIBUTION, PERCENT

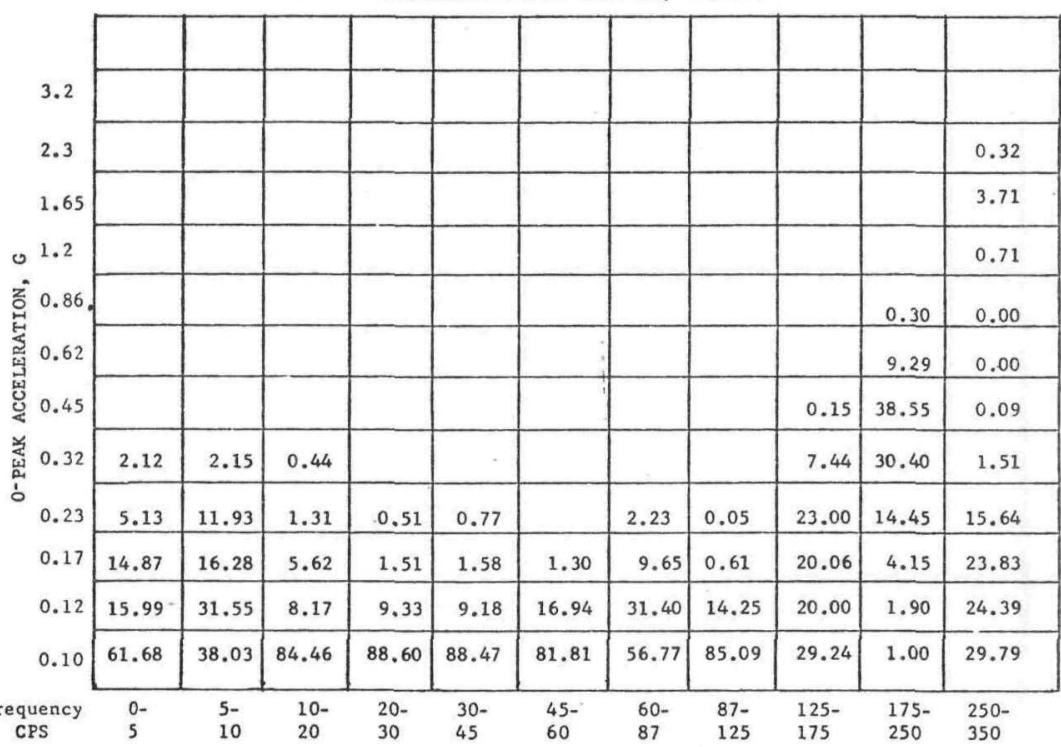

No. of Peaks

Counted
$94 \quad 92 \quad 232 \quad 396$
642 $\begin{array}{llllll}945 & 1039 & 1865 & 2792 & 2991 & 2534\end{array}$ Total No. of Peaks Counted: 13,622 
TABLE A-VI

Normal Conditions

(Vertical axis, forward and aft locations)

Driving On Heavily Patched Asphalt Highway at $50 \mathrm{mph}$ ACCELERATION DISTRIBUTION, PERCENT

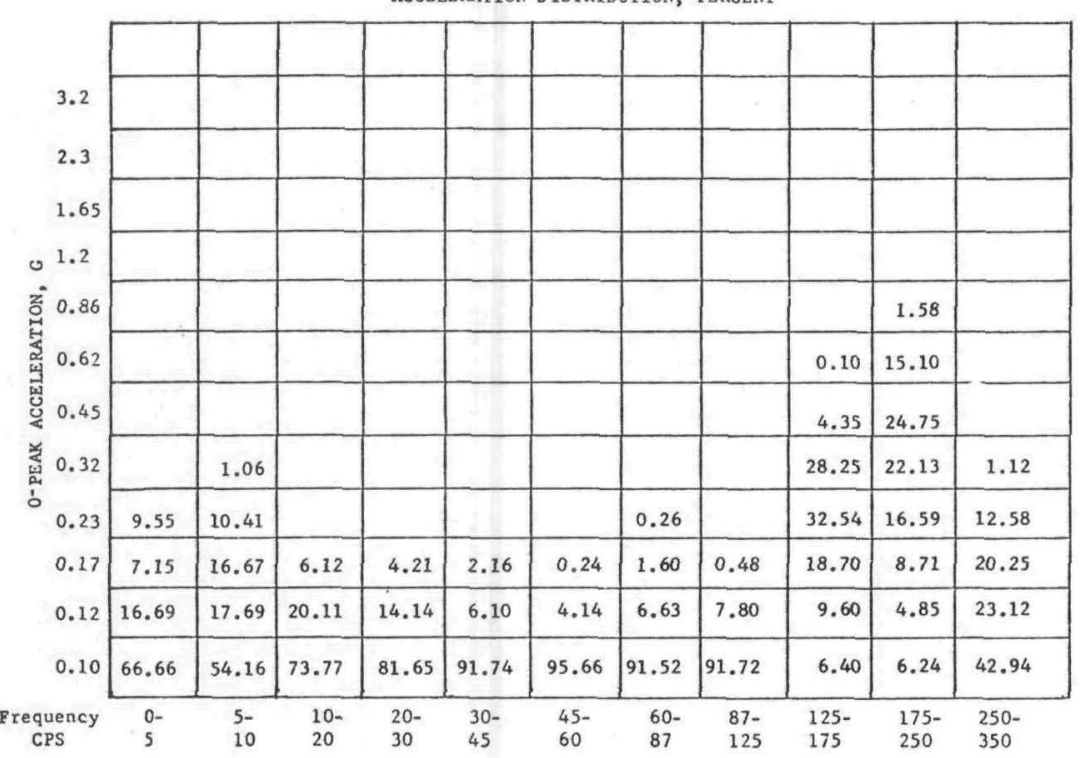

No. of Peaks
Counted
$84 \quad 96$
403
606

Driving on Heavily Patched Asphalt Highway at $30 \mathrm{mph}$ ACCELERATION DISTRIBUTION, PERCENT

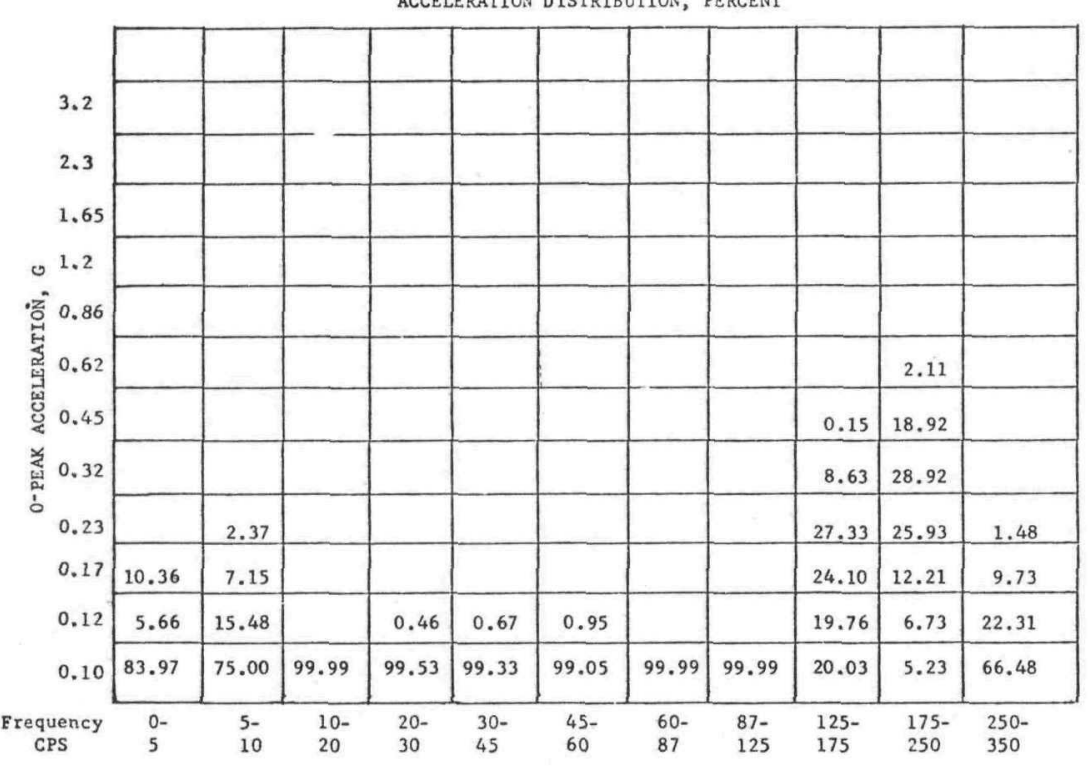

No. of Peaks

Counted 106
$84 \quad 25$ 


\section{TABLE A-VII}

Normal Conditions

(Vertical axis, forward and aft locations)

Driving On Access Road Parallel to Interstate Highway

ACCELERATION DISTRIBUTION, PERCENT

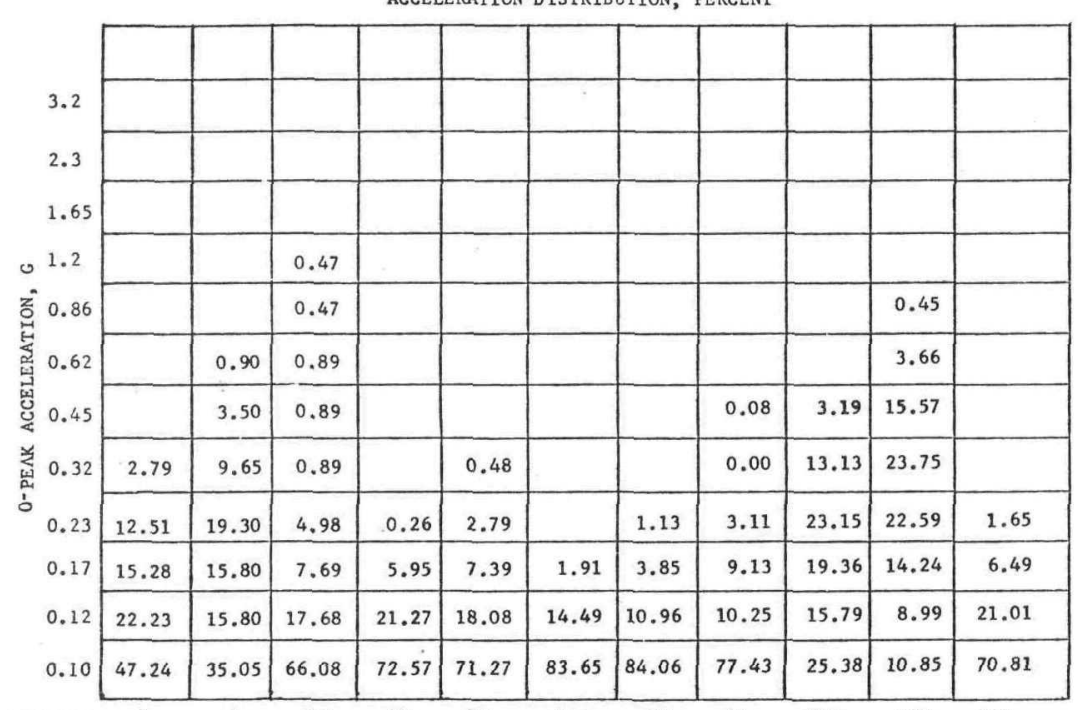

$\begin{array}{clllllllllll}\text { Frequency } & 0- & 5- & 10- & 20- & 30- & 45- & 60- & 87- & 125- & 175- & 250- \\ \text { CPS } & 5 & 10 & 20 & 30 & 45 & 60 & 87 & 125 & 175 & 250 & 350\end{array}$

No. of Peaks

counted

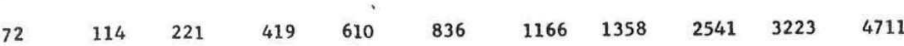

Total No, of Peaks Counted: 15,271

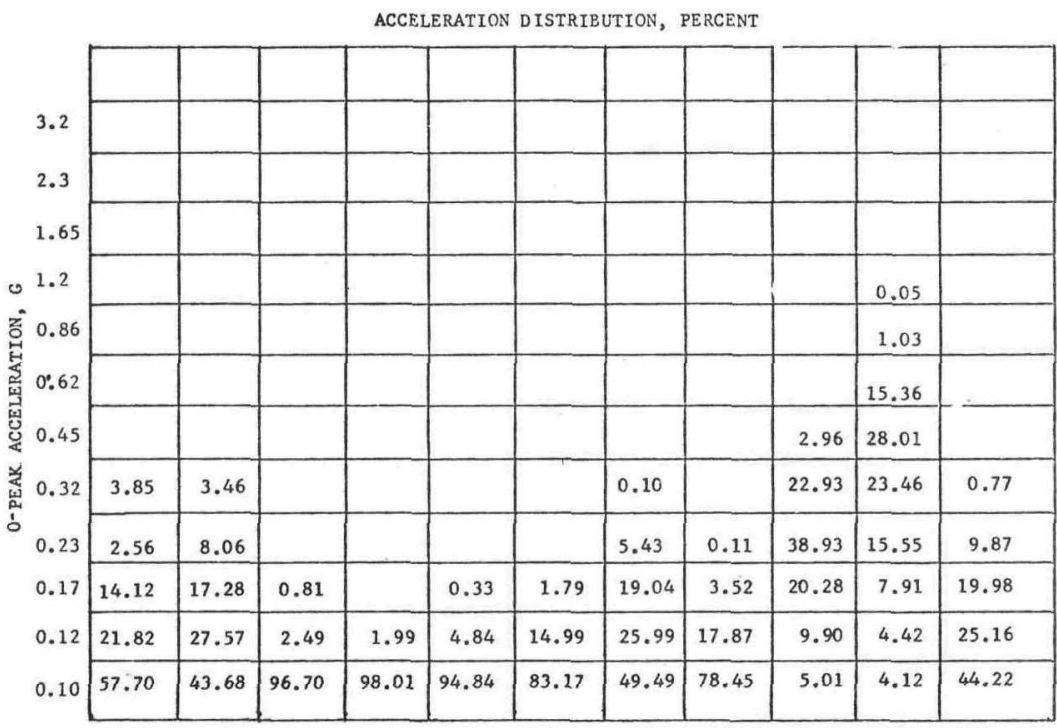

$\begin{array}{clllllllllll}\text { Frequency } & 0- & 5- & 10- & 20- & 30- & 45- & 60- & 87- & 125- & 175- & 250- \\ \text { CPS } & 5 & 10 & 20 & 30 & 45 & 60 & 87 & 125 & 175 & 250 & 350\end{array}$

No. of Peaks

Counted

$\begin{array}{lllllllllll}78 & 87 & 242 & 404 & 642 & 939 & 1035 & 1716 & 2547 & 3097 & 4798\end{array}$

Total No, of Peaks Counted: 15,585 
TABLE A-VIII

Normal Conditions

(Vertical axis, forward and aft locations)

Driving On Interstate Highway at 50-55 mph

ACCELERATION DISTRIBUTION, PERCENT

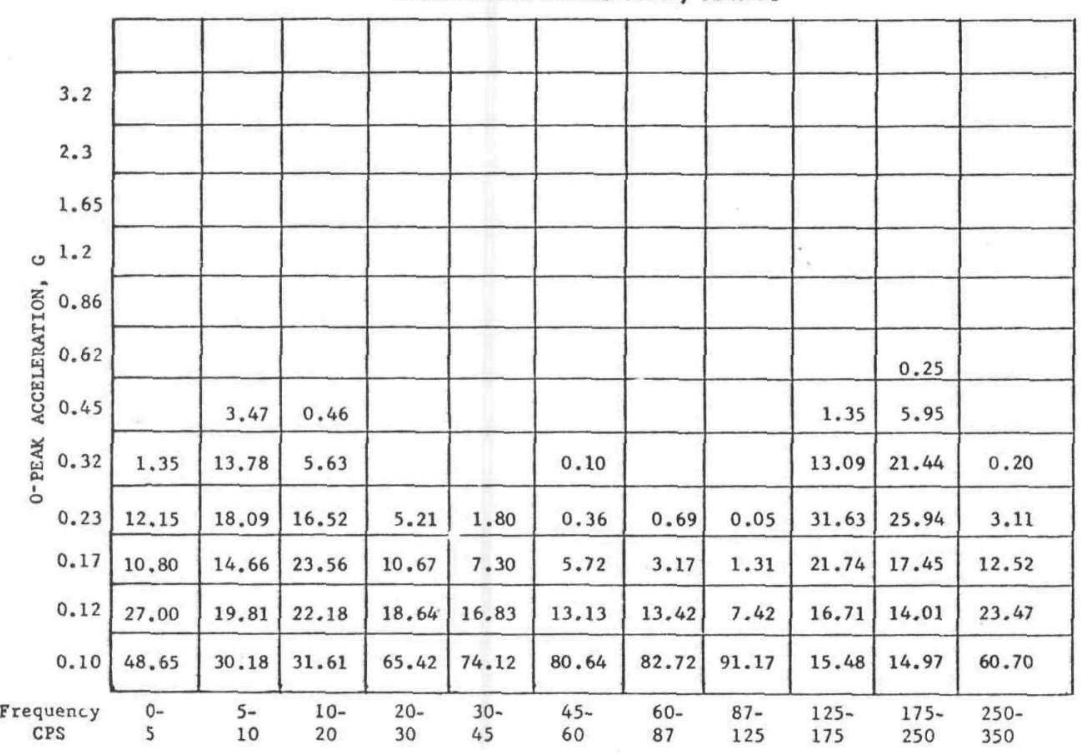

No. of Peaks

$\begin{array}{lllllllllll}74 & 116 & 212 & 402 & 618 & 859 & 1168 & 1801 & 2521 & 3349 & 4642\end{array}$

Total No, of Peaks Counted: 15,762
Driving on Level Blacktop Interstate Highway at $35 \mathrm{mph}$ ACCELERATION DISTRIBUTION, PERCENT

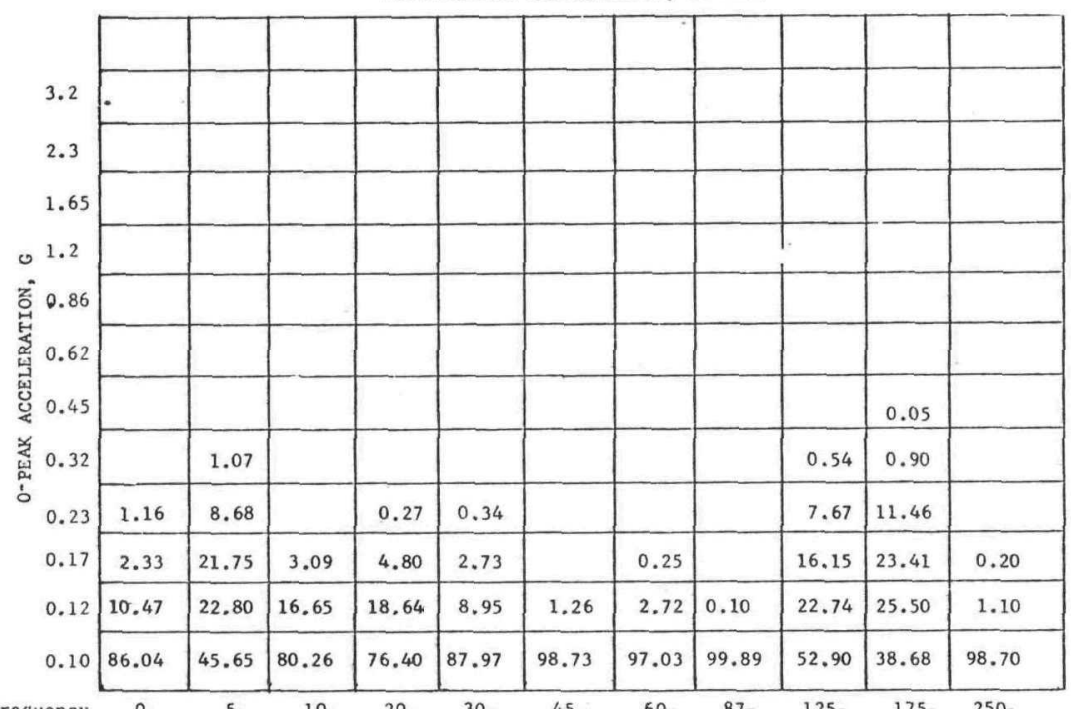

$$
\begin{array}{clllllllllll}
\text { requency } & 0- & 5- & 10- & 20- & 30- & 45- & 60- & 87- & 125- & 175- & 250- \\
\text { CPS } & 5 & 10 & 20 & 30 & 45 & 60 & 87 & 125 & 175 & 250 & 350
\end{array}
$$

No. of Peaks

Counted

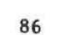


TABLE A-IX

Normal Conditions

(Vertical axis, forward and aft locations)

Driving in Paved Construction Zone at $45 \mathrm{mph}$ ACCELERATION DISTRIBUTION, PERCEN

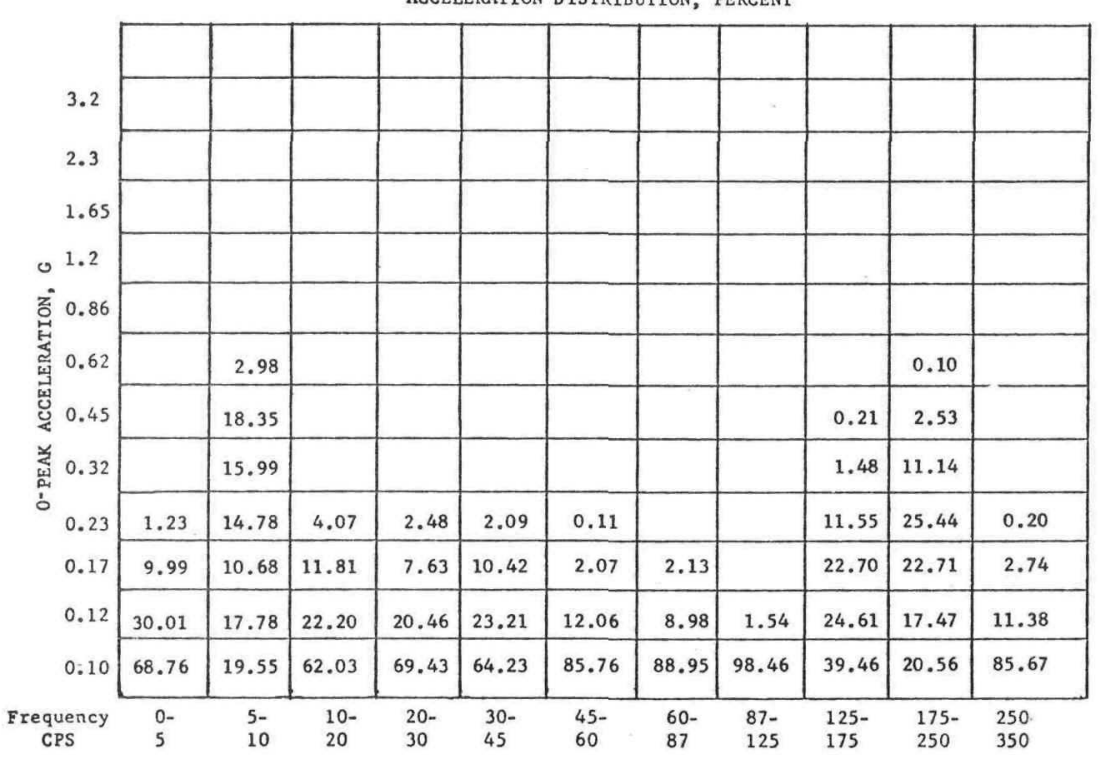

No. of Peaks

counted

80
169
406
822

$\begin{array}{llllll}1138 & 1759 & 2598 & 3163 & 4641\end{array}$
Driving in Paved Construction Zone at $55 \mathrm{mph}$

ACCELERATION DISTRIBUTION, PERCENT

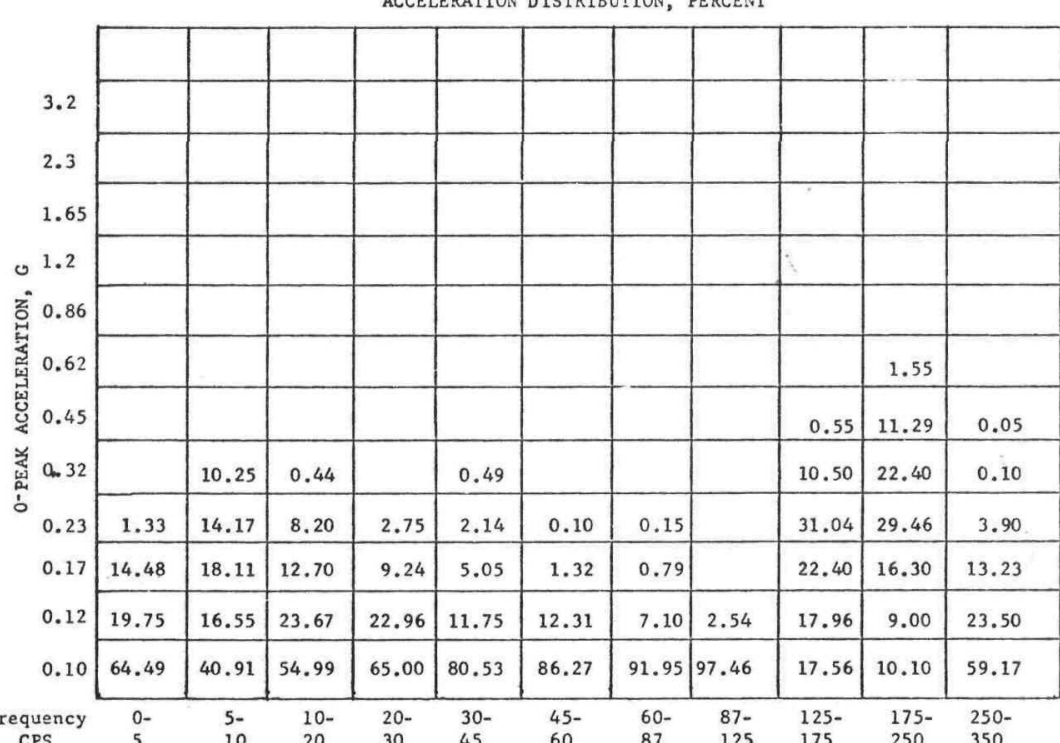

$\begin{array}{llllllllllll}\text { requency } & 0- & 5- & 10- & 20- & 30- & 45- & 60- & 87- & 125- & 175- & 250- \\ \text { CPS } & 5 & 10 & 20 & 30 & 45 & 60 & 87 & 125 & 175 & 250 & 350\end{array}$

No. of Peaks

counted

76
$127 \quad 220$ 
TABLE A-X

Normal Conditions

(Vertical axis, forward and aft locations)

Driving On Rough Blacktop at $60 \mathrm{mph}$

ACCELERATION DISTRIBUTION, PERCEN

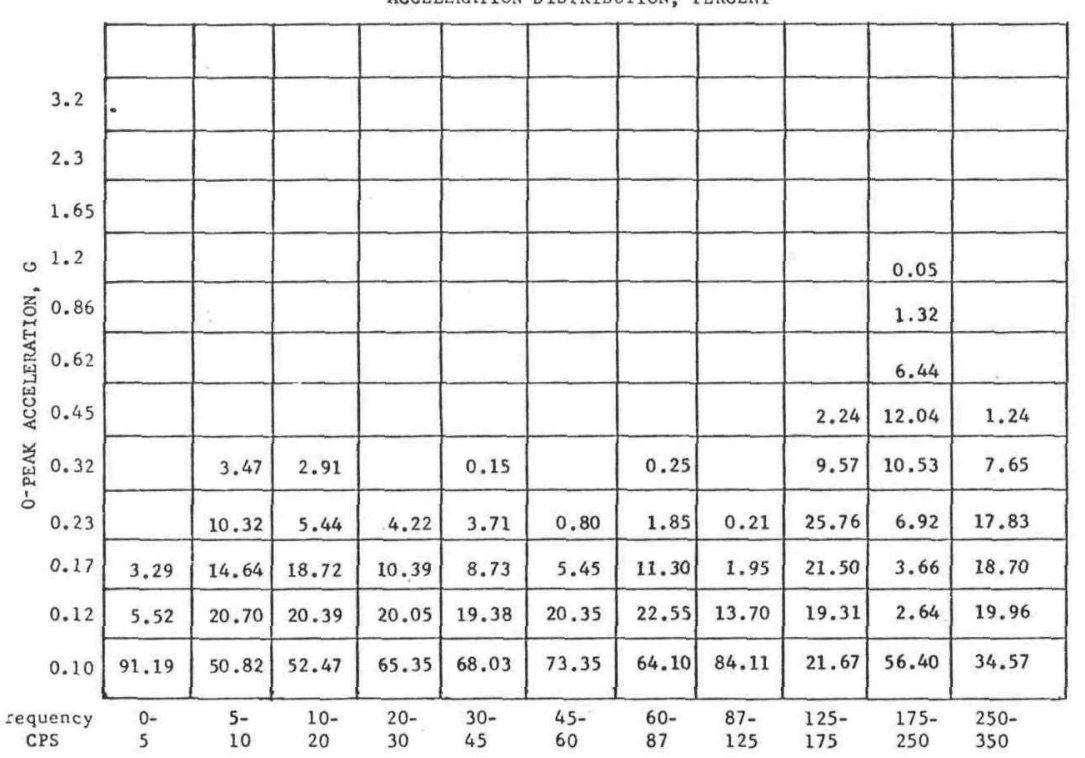

No. of Peaks

Counted

116

240

$404 \quad 594$

$\begin{array}{llllll}894 & 1092 & 1823 & 2760 & 2910 & 4652\end{array}$

Total No. of Peaks Counted: 15,576 
TABLE A-XI

Composite of All Normal Situations

(Vertical axis, forward and aft locations)

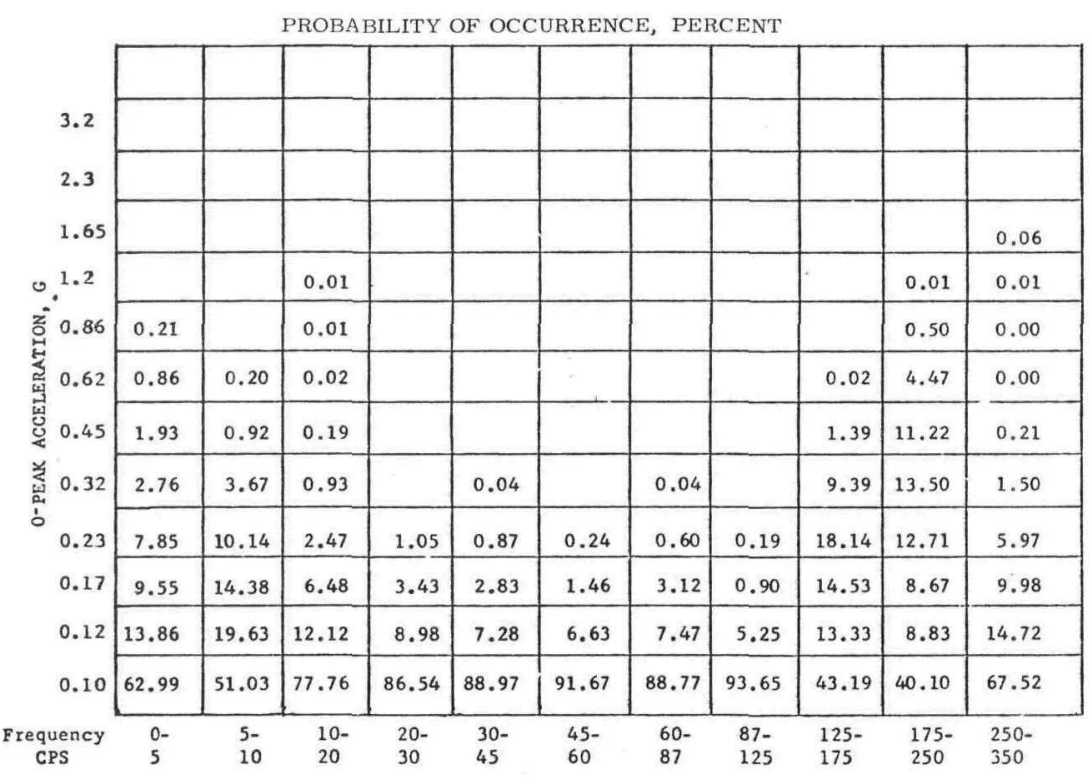

No. of Peaks

Note: Acceleration distributions less than $0.01 \%$ are not reported.
Total No. of Peaks Counted: 273,995

\section{TABLE A-XII}

Normal Conditions

Frequency of Occurrence

Weight applied to road types for deriving composite descriptions of environment:

\section{Event}

Weight

1. Backing up to dock

1

2. Crossing railroad tracks

3. Dip

4. Low level to high

5. Overpass

6. Asphalt road at $50 \mathrm{mph}$

7. Access road

8. Four-lane highway

9. Construction zone

10. Blacktop at $60 \mathrm{mph}$
2

2

1

10

1. 5

1. 5

1.0

10 


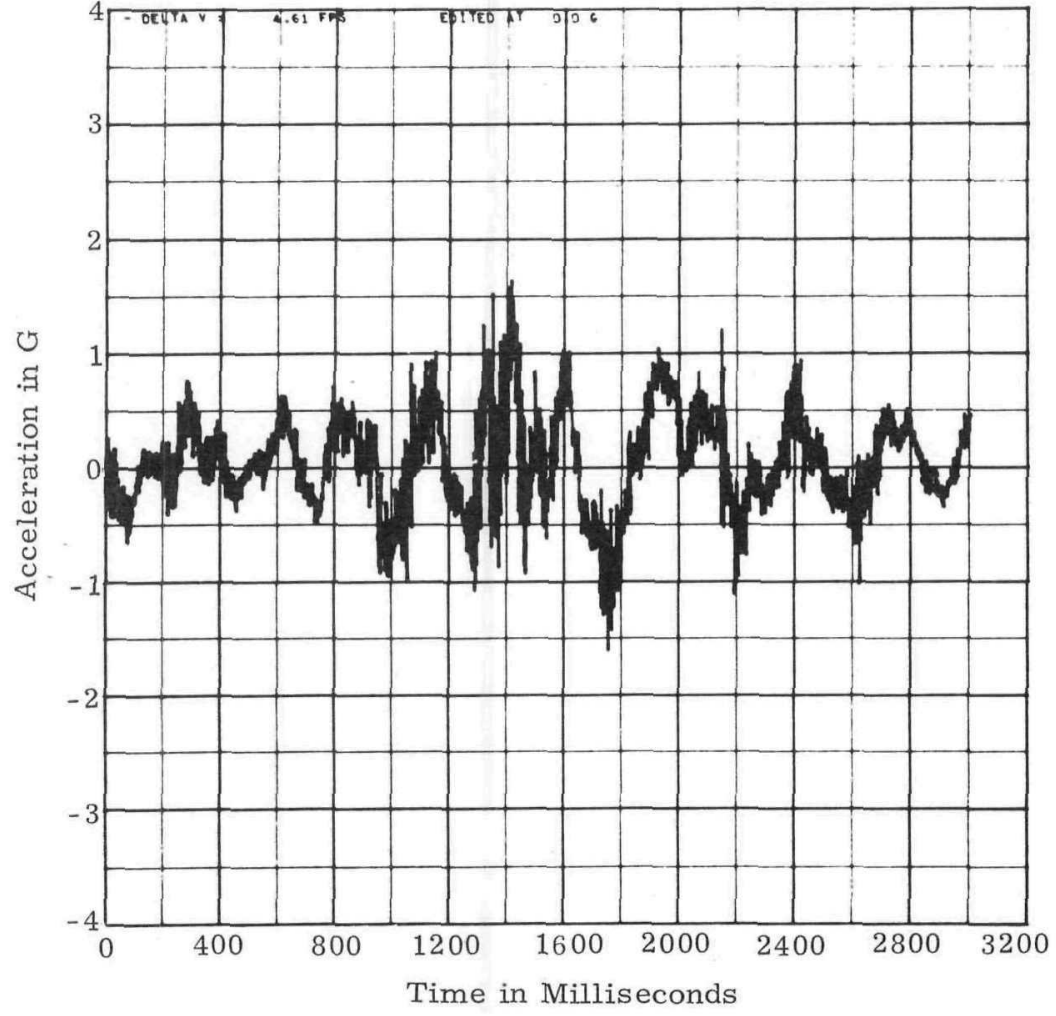

Figure A-1. Driving Across Railroad Tracks at Stockyards Vertical, Aft on Truck Bed (Channel 1)

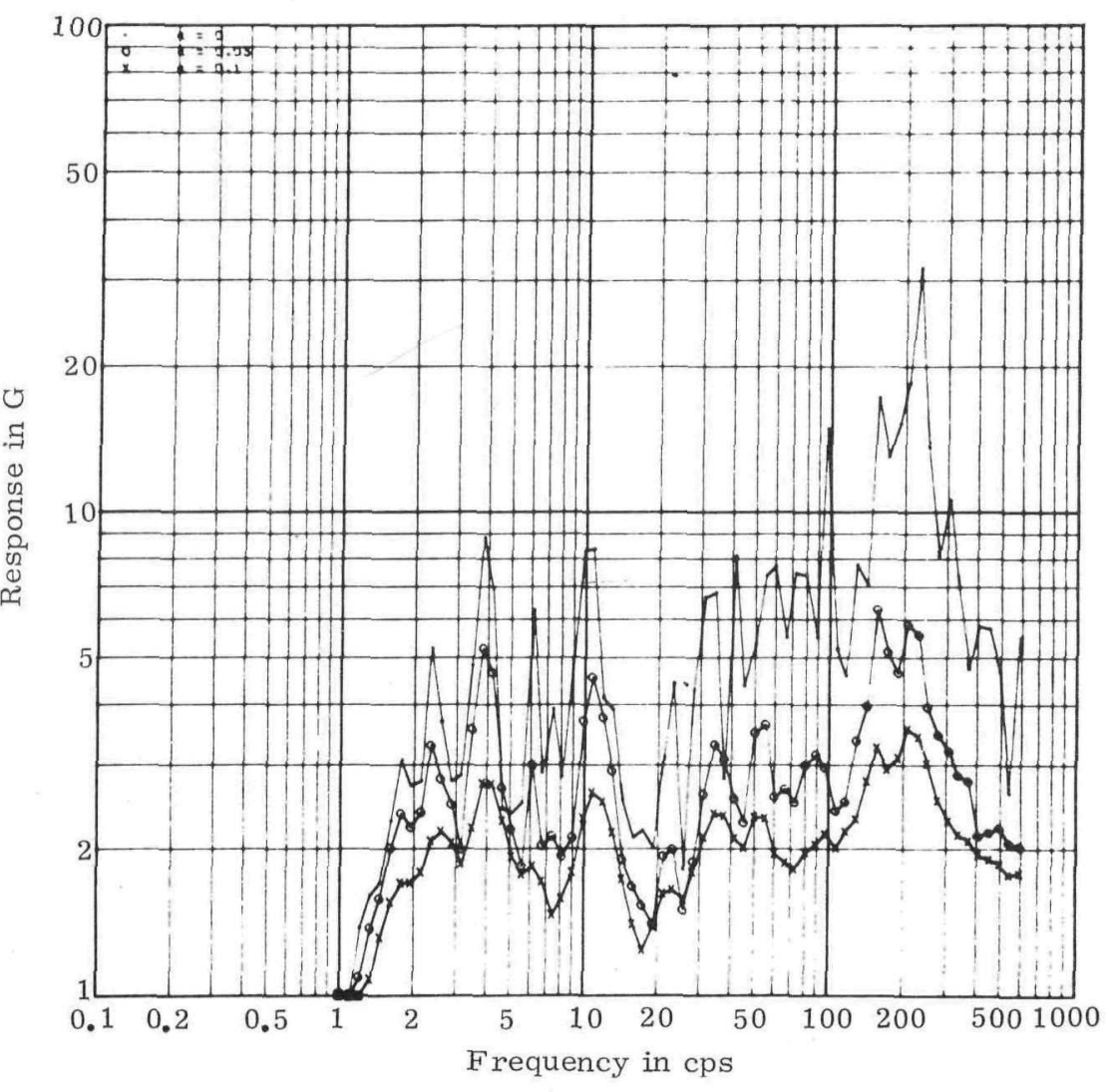

Figure A-2. Driving Across Railroad Tracks at Stockyards Vertical, Aft on Truck Bed (Channel 1) 
APPENDIX B

ABNORIMAL CONDITIONS 
TABLE B-I

Abnormal Conditions

(Vertical axis, forward and aft locations)

Driving With Two Wheels on Shoulder at $45 \mathrm{mph}$

ACCELERATION DISTRIBUTION, PE

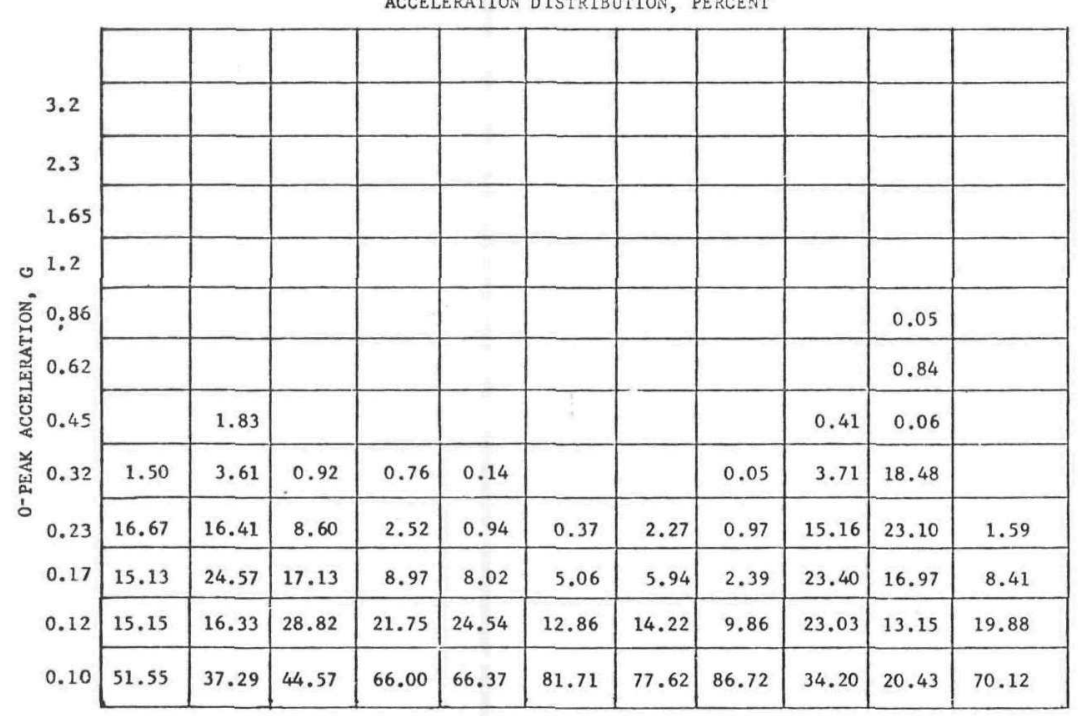

$\begin{array}{llllllllllll}\text { requency } & 0- & 5- & 10- & 20- & 30- & 45- & 60- & 87- & 125- & 175- & 250- \\ \quad \text { CPS } & 5 & 10 & 20 & 30 & 45 & 60 & 87 & 125 & 175 & 250 & 350\end{array}$

No. of Peaks

$\begin{array}{lllllllllll}66 & 110 & 222 & 400 & 636 & 847 & 1161 & 1764 & 2542 & 3248 & 4659\end{array}$

Total No. of Peaks Counted: 15,655
TABLE B-II

Abnormal Conditions

(Vertical axis, forward and aft locations)

Driving With Four Wheels on Shoulder at $45 \mathrm{mph}$

ACCELERATION DISTRIBUTION, PERCENT

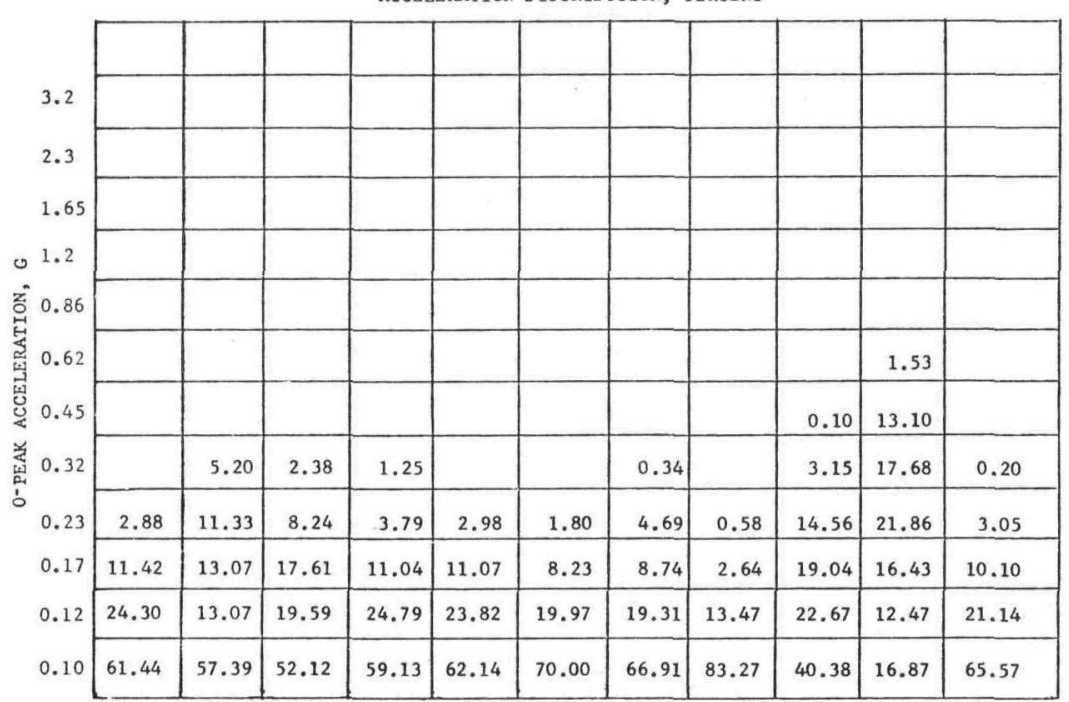

$\begin{array}{llllllllllll}\text { requency } & 0- & 5- & 10- & 20- & 30- & 45- & 60- & 87- & 125- & 175- & 250- \\ \text { CPS } & 5 & 10 & 20 & 30 & 45 & 60 & 87 & 125 & 175 & 250 & 350\end{array}$

No. of Peaks

Counted

70

642

$\begin{array}{llllll}27 & 1171 & 1737 & 2567 & 3241 & 4643\end{array}$

Total No. of Peaks Counted: 15,667 


\section{TABLE B-III}

Abnormal Conditions

(Vertical axis, forward and aft locations)

Driving Off Road in Desert Brush

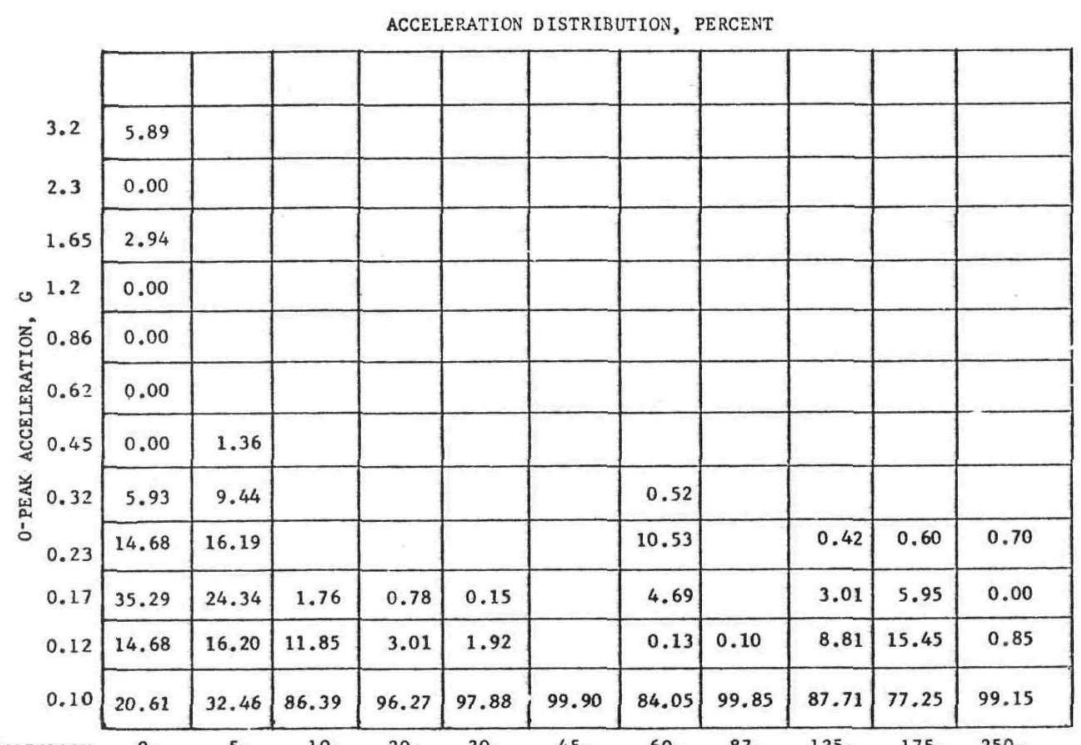

$\begin{array}{clllllllllll}\text { Frequency } & 0- & 5- & 10- & 20- & 30- & 45- & 60- & 87- & 125- & 175- & 250- \\ \text { CPS } & 5 & 10 & 20 & 30 & 45 & 60 & 87 & 125 & 175 & 250 & 350\end{array}$

No. of Peaks

Nounted

$\begin{array}{lllllllllll}34 & 74 & 227 & 401 & 622 & 837 & 769 & 1701 & 2321 & 3270 & 4770\end{array}$

Total No. of Peaks Counted: 15,026
TABLE B-IV

Abnormal Conditions

(Vertical axis, forward and aft locations)

Driving Into a Dip at $50 \mathrm{mph}$

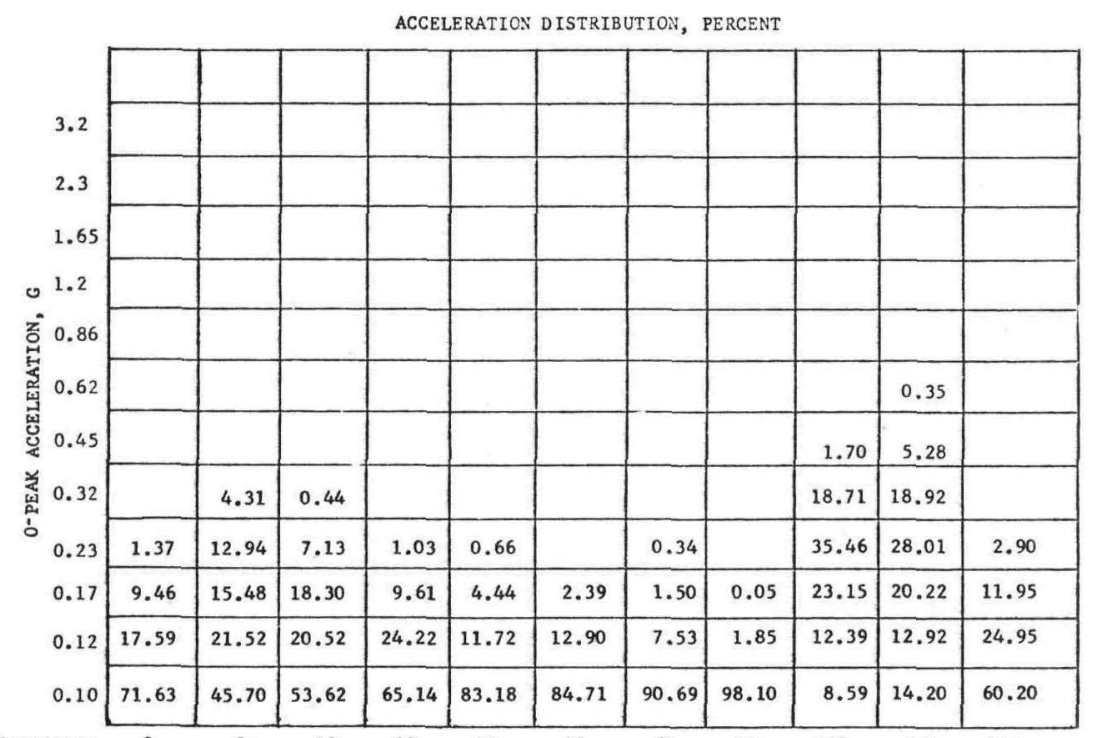

$\begin{array}{clllllllllll}\text { Frequency } & 0- & 5- & 10- & 20- & 30- & 45 & 60- & 87- & 125- & 175- & 250- \\ \text { CPS } & 5 & 10 & 20 & 30 & 45 & 60 & 87 & 125 & 175 & 250 & 350\end{array}$

No. of Peaks
Counted

$\begin{array}{lllllllllll}74 & 116 & 224 & 396 & 607 & 875 & 1136 & 1810 & 2581 & 3389 & 4776\end{array}$

Total No. of Peaks Counted: 15, 984 
TABLE B-V

Abnormal Conditions

(Vertical axis, forward and aft locations)

Driving on Median Between Access Road and Interstate Highway

ACCELERATION DISTRIBUTION, PERCENT

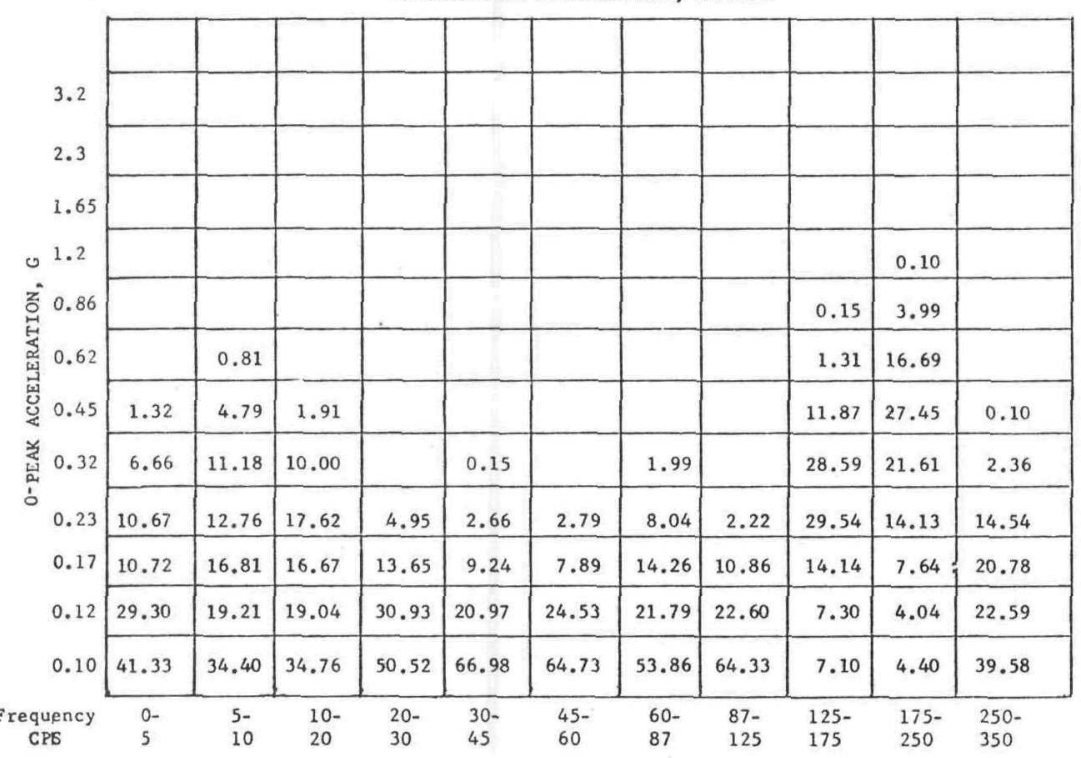

No. of Peaks

Counted

$75 \quad 125$ $\begin{array}{llllll}860 & 1105 & 1795 & 2558 & 3139 & 4668\end{array}$

Total No. of Peaks Counted: 15,578
TABLE B-VI

Abnormal Conditions

(Vertical axis, forward and aft locations)

Driving on Dirt Road at $45 \mathrm{mph}$

ACCELERATION DISTRIBUTION, PERCENT

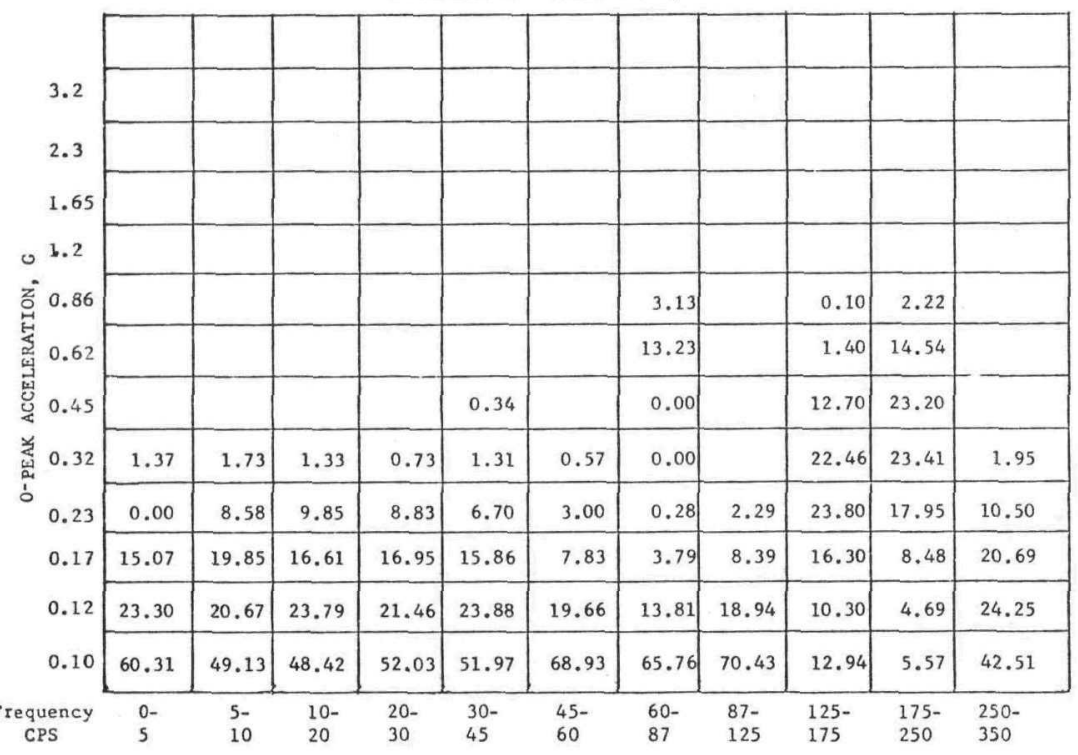

No. of Peaks

Counted

$\begin{array}{lllllllllll}73 & 116 & 223 & 419 & 612 & 865 & 733 & 1757 & 2647 & 3220 & 4604\end{array}$

Total No. of Peaks Counted: 15,269 

G-Time (Input at Truck Bed)

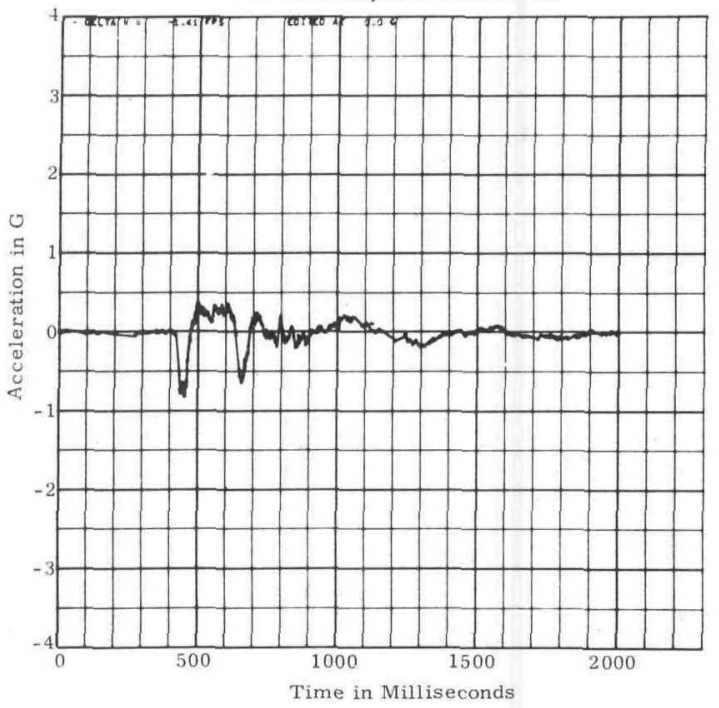

Figure B-1. Backing Into Loading Dock Longitudinal, Aft on Truck Bed (Channel 2)

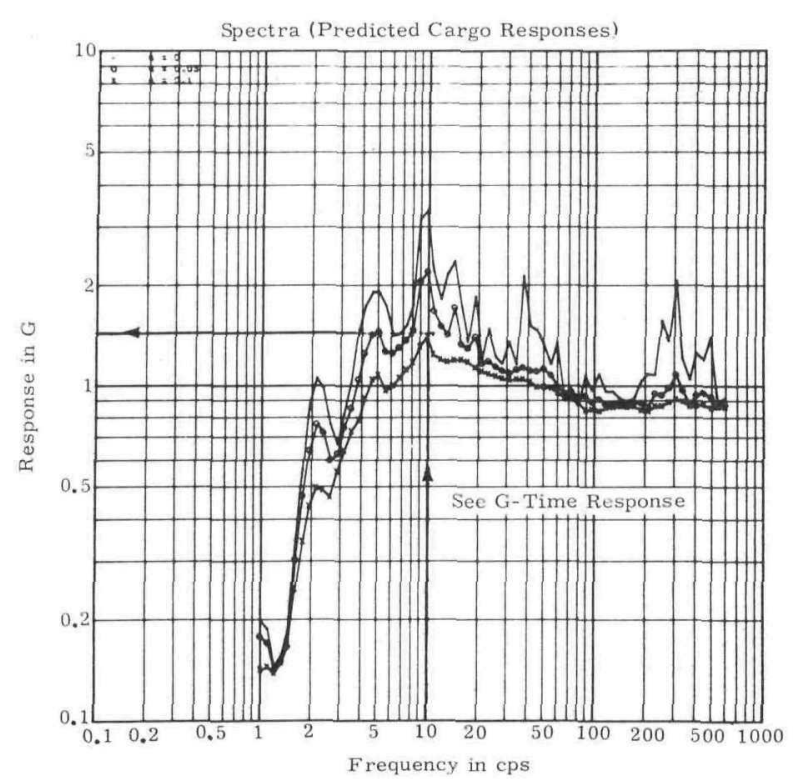

Figure B-2. Backing Into Loading Dock Longitudinal, Aft on Truck Bed (Channel 2)

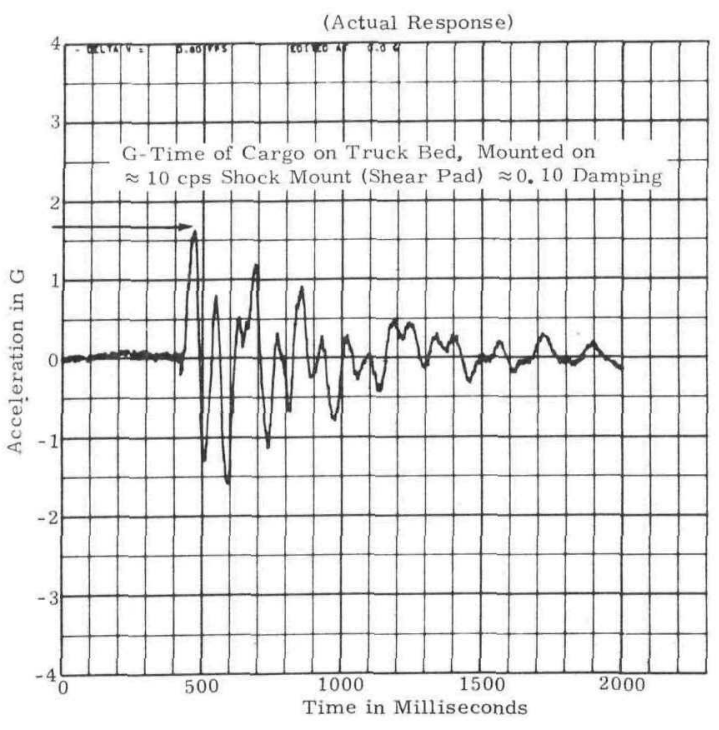

Figure B-3. Backing Into Loading Dock Longitudinal, on Beech Dewar Mount (Channel 6) 


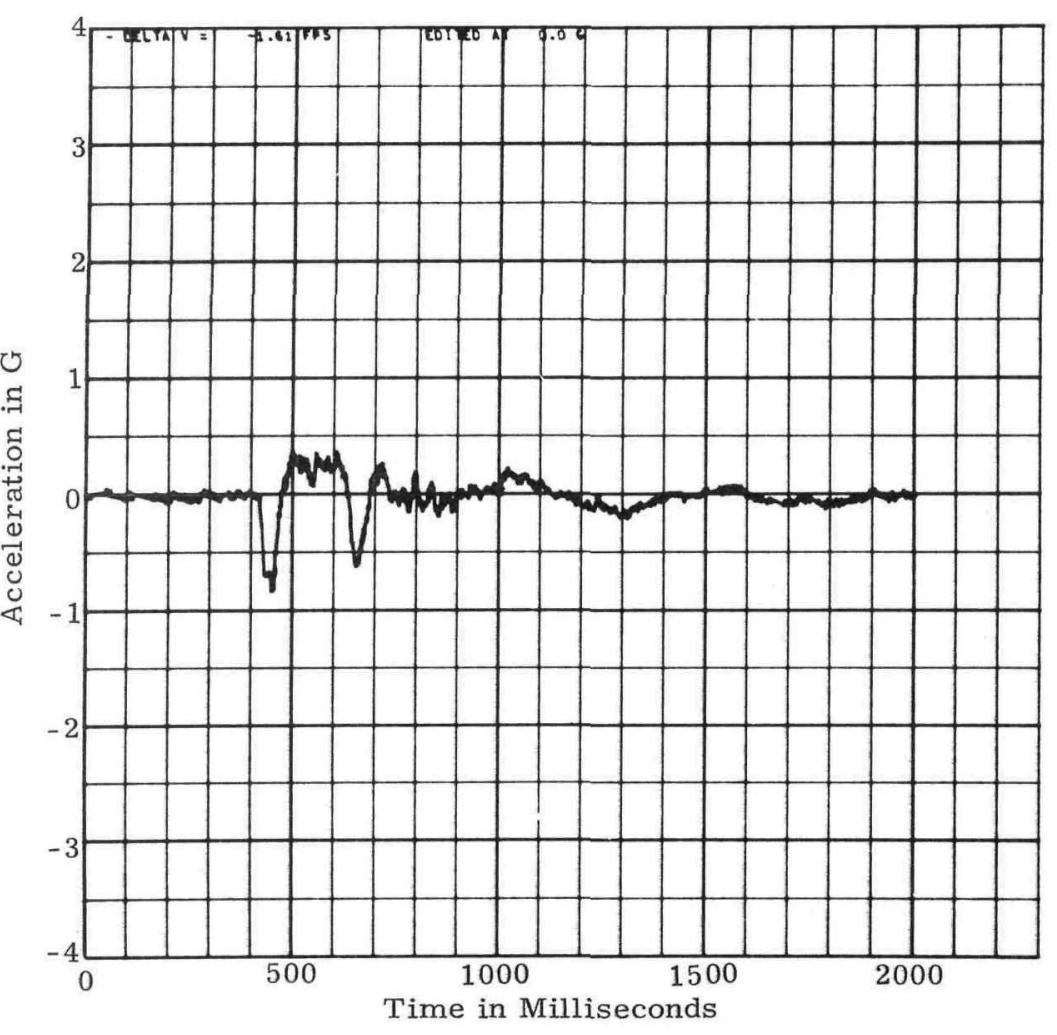

Figure B-4. Backing Into Loading Dock -

Longitudinal, Forward on Truck Bed (Channel 4)

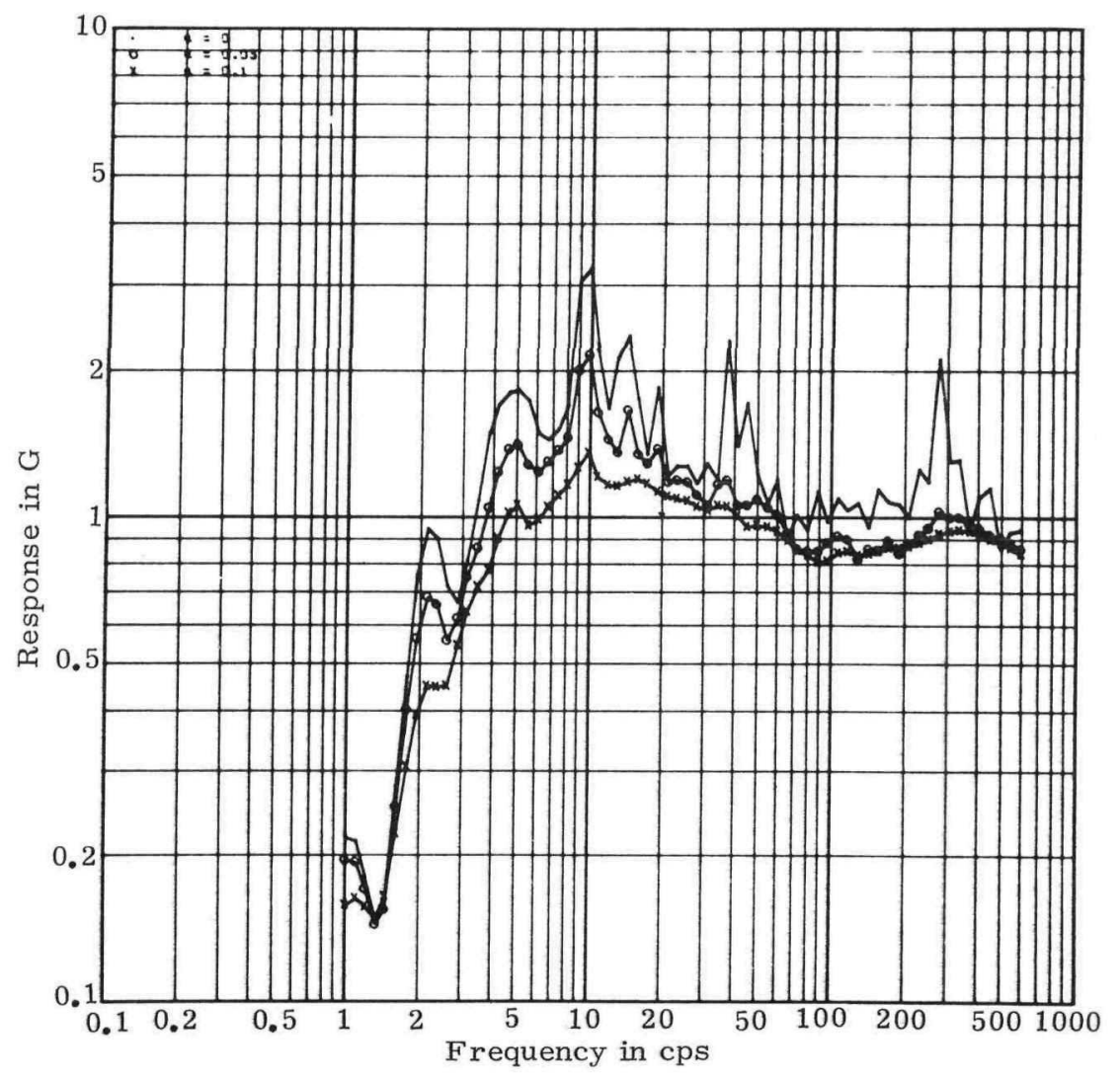

Figure B-5. Backing Into Loading Dock -

Longitudinal, Forward on Truck Bed (Channel 4) 


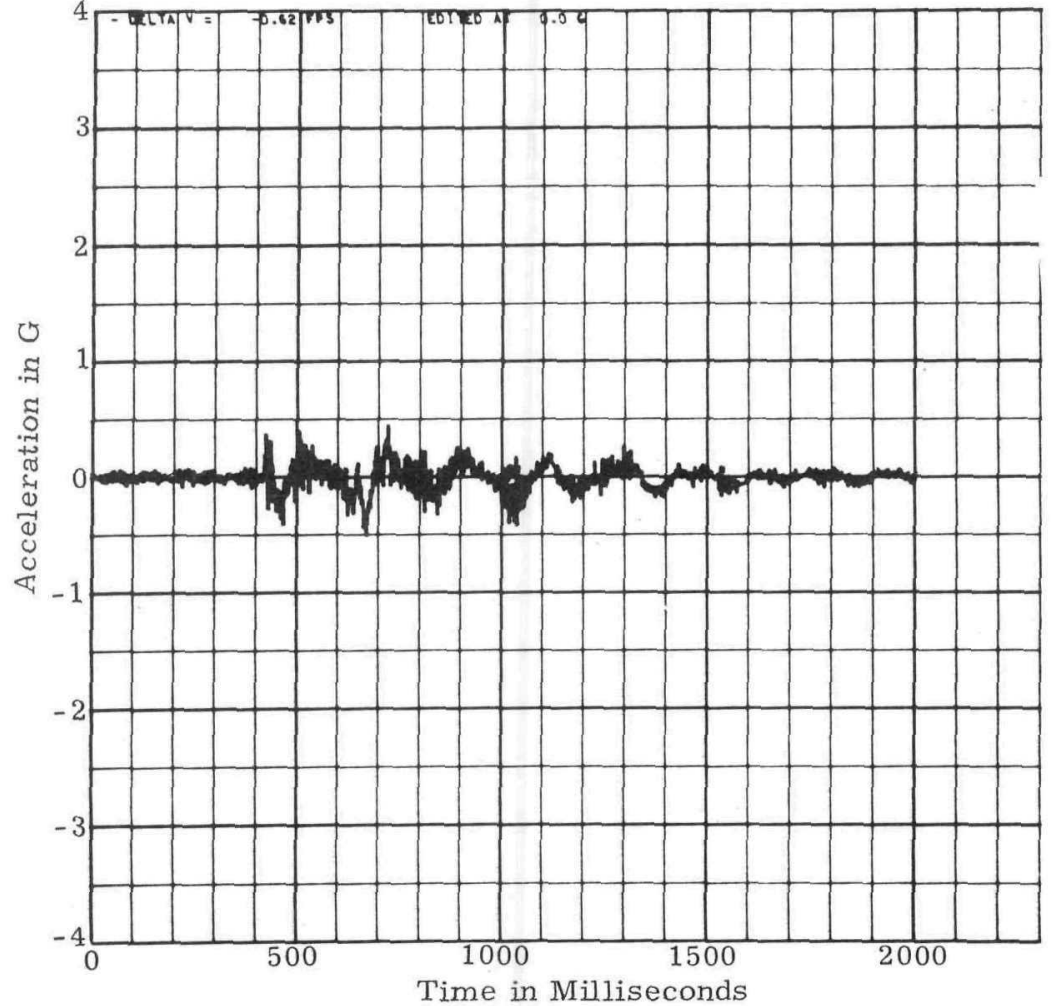

Figure B-6. Backing Into Loading Dock -

Vertical, Truck Bed Aft of Pallet (Channel 1)

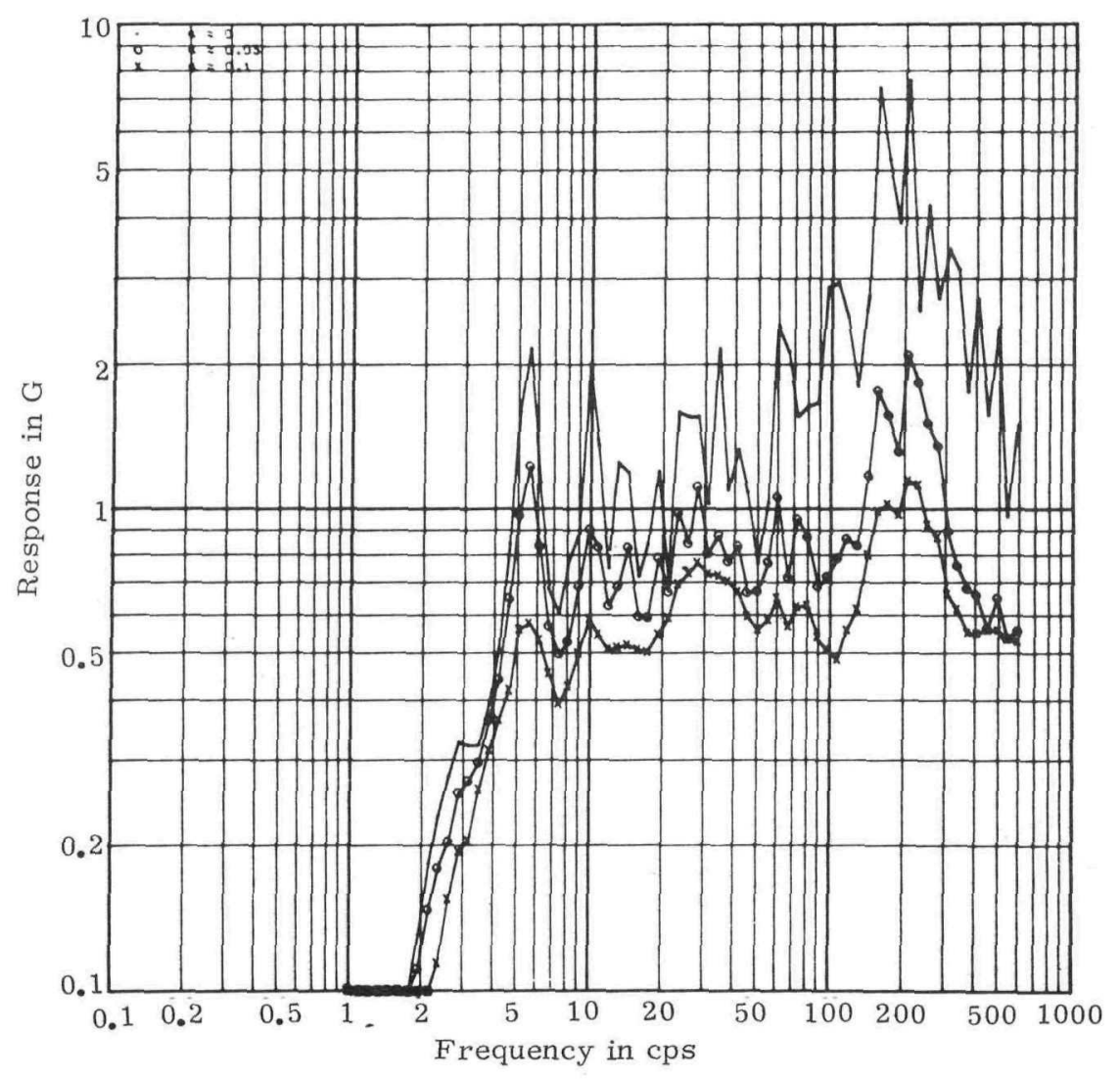

Figure B-7. Backing Into Loading Dock -

Vertical, Truck Bed Aft of Pallet (Channel 1) 


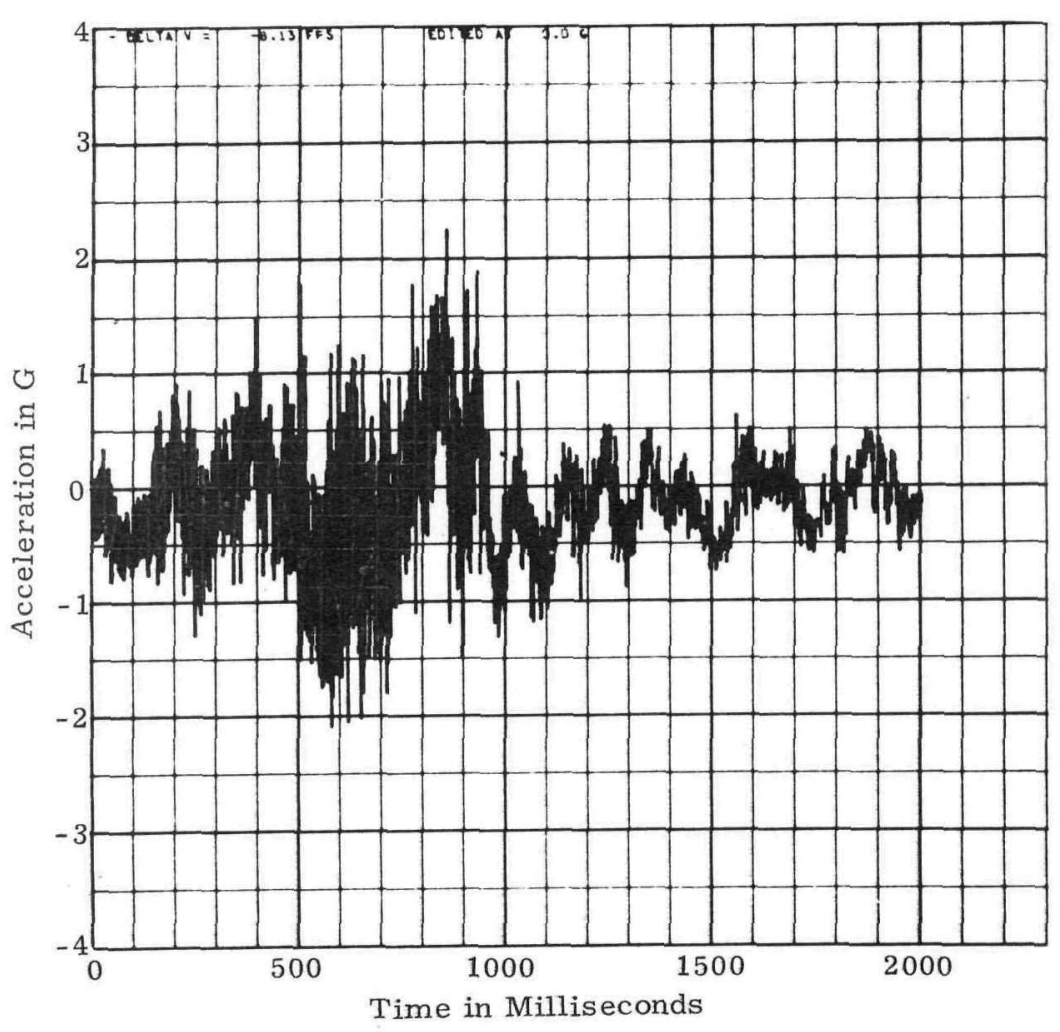

Figure B-8. Driving Across Railroad Tracks at $\approx 45 \mathrm{mph}$ Vertical, Aft on Truck Bed (Channel 1)

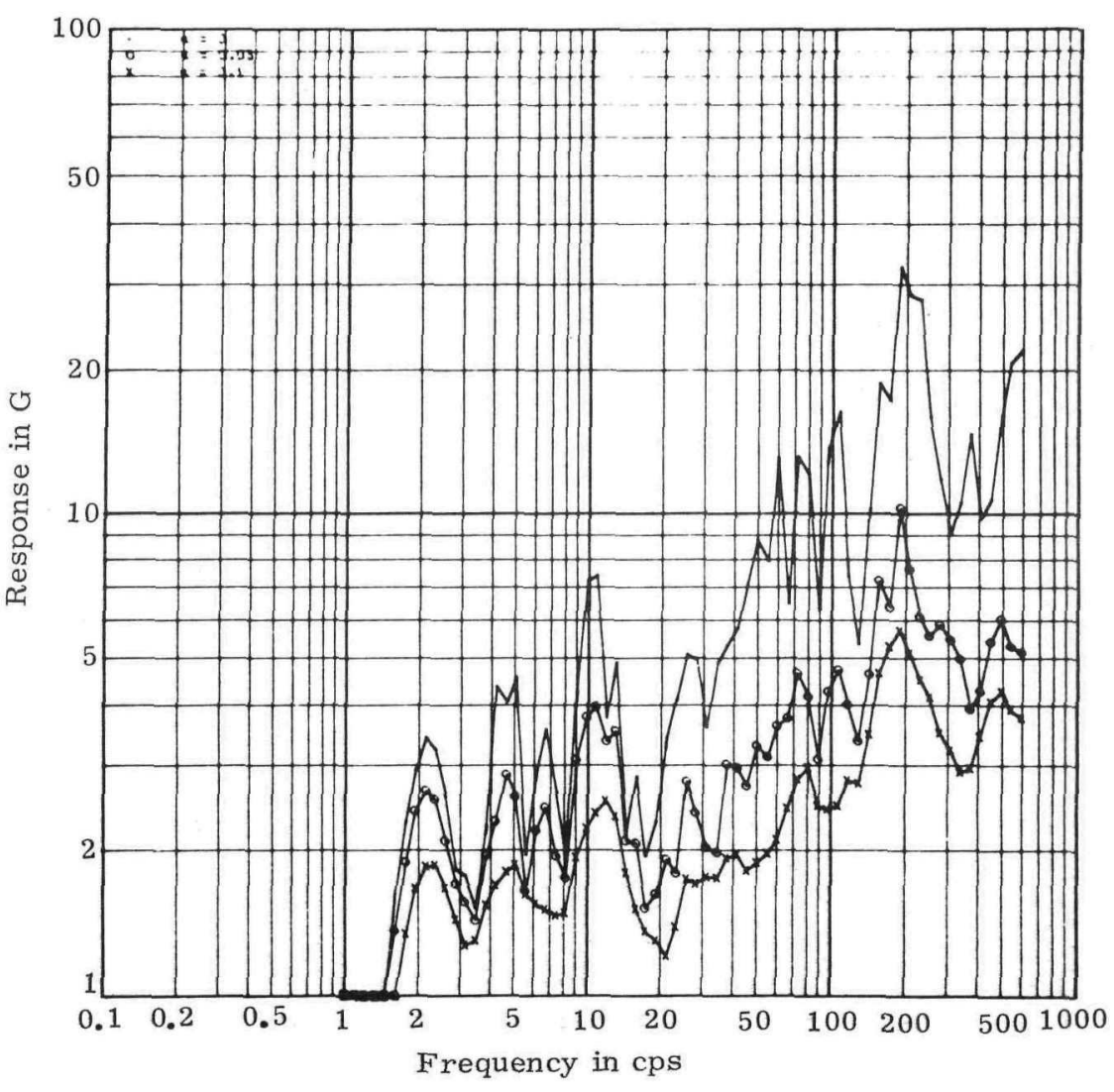

Figure B-9. Driving Across Railroad Tracks at $45 \mathrm{mph}$ Vertical, Aft on Truck Bed (Channel 1) 


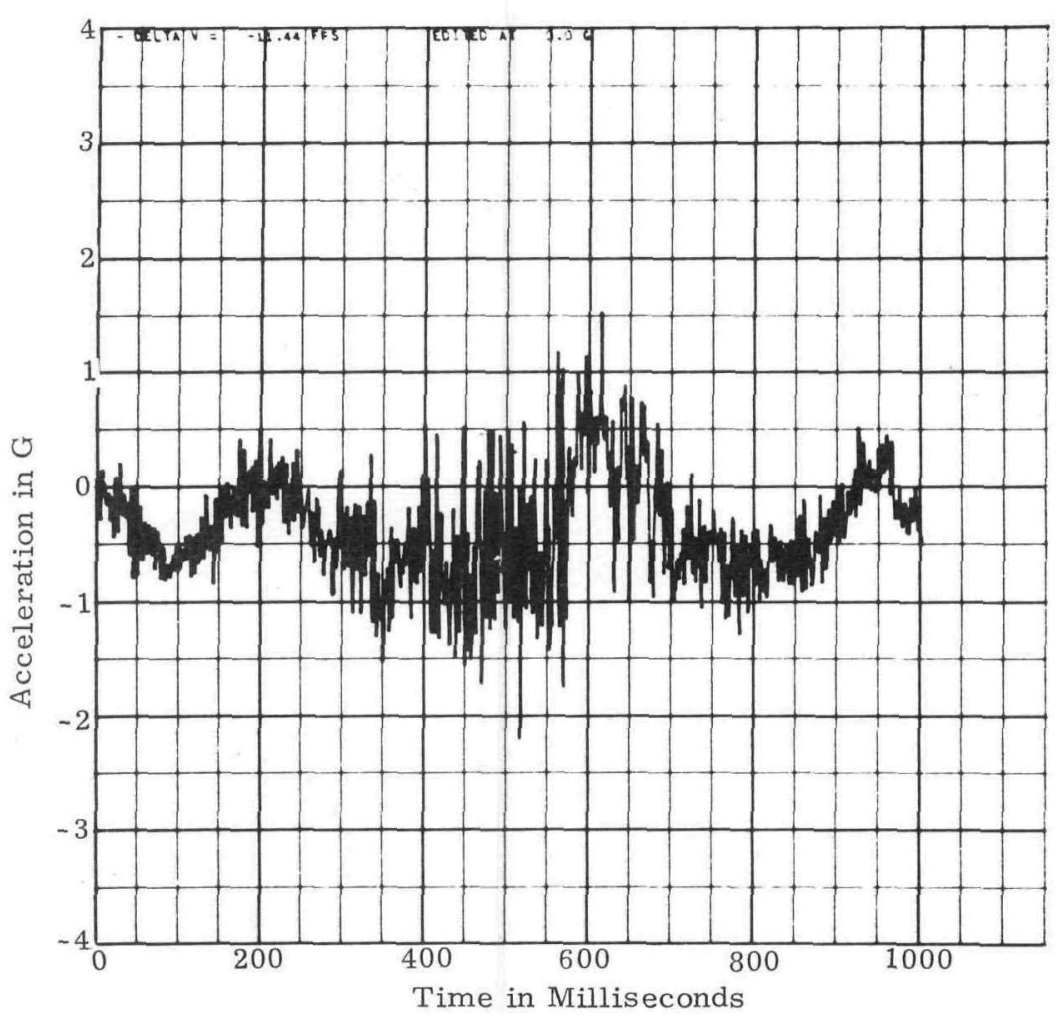

Figure B-10. Driving Across Railroad Tracks at $50 \mathrm{mph}$ Vertical, Aft on Truck Bed (Channel 1)

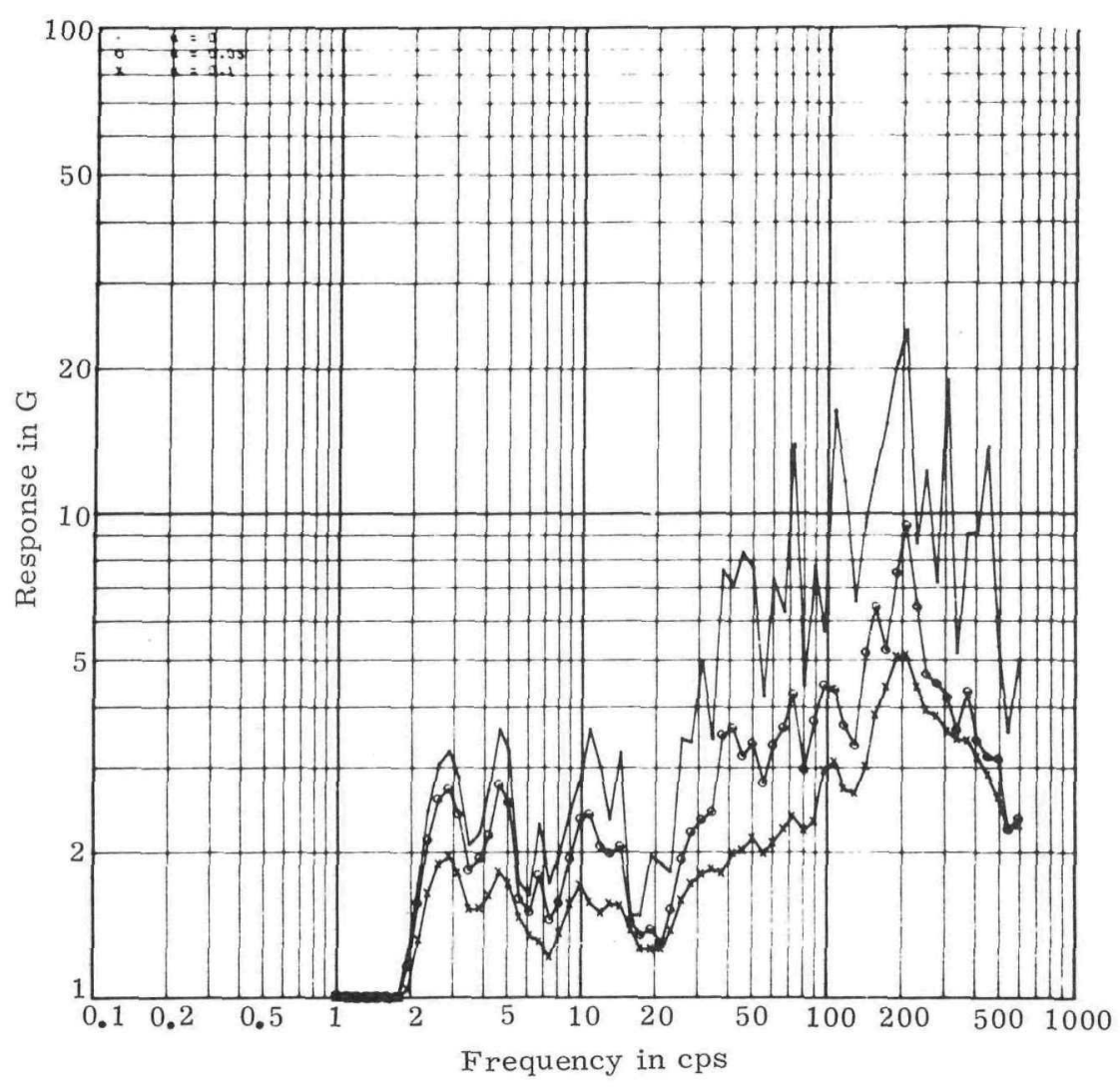

Figure B-11. Driving Across Railroad Tracks at $50 \mathrm{mph}$ Vertical, Aft on Truck Bed (Channel 1) 


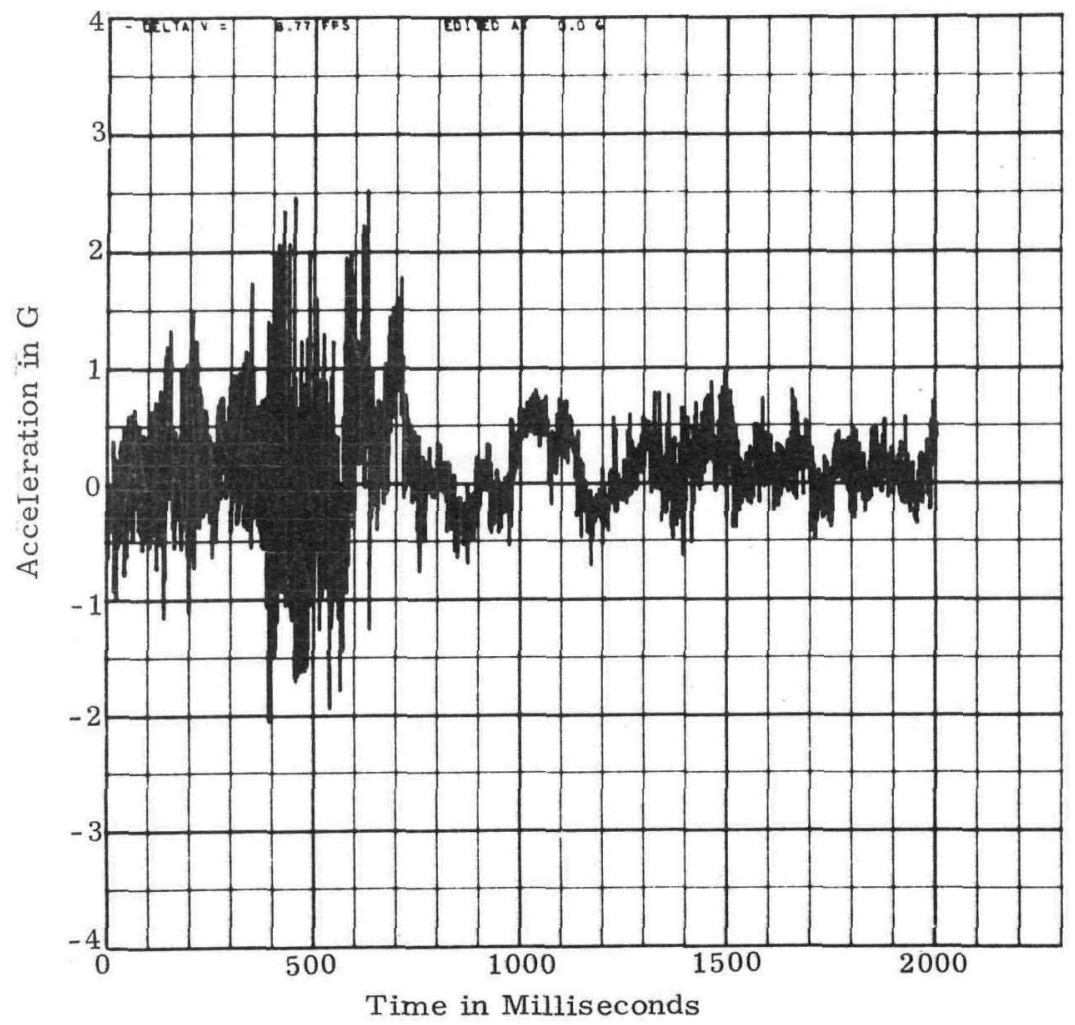

Figure B-12. Driving Across Cattle Guard at $45 \mathrm{mph}$ Vertical, Aft on Truck Bed (Channel 1)

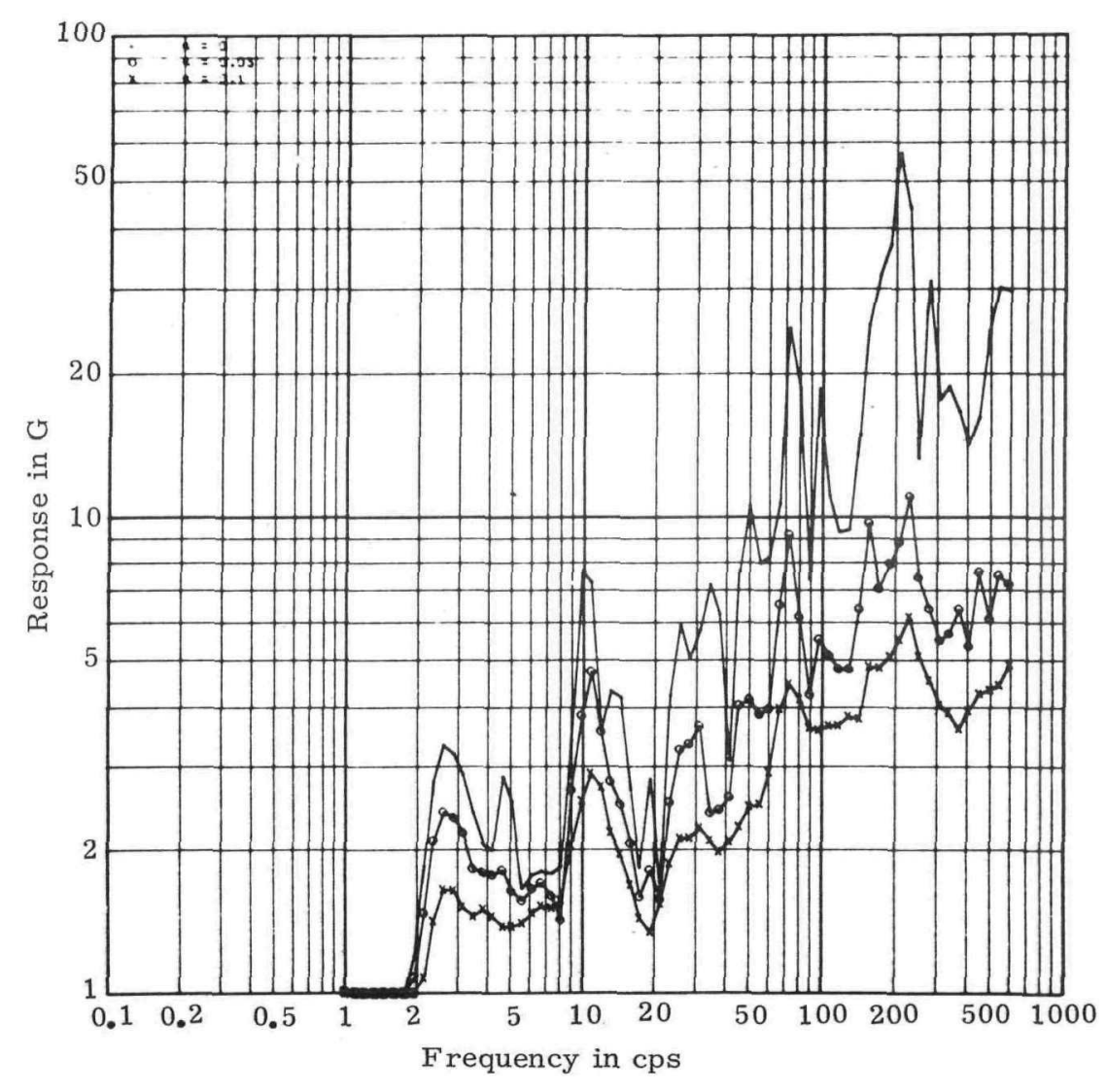

Figure B-13. Driving Across Cattle Guard at $45 \mathrm{mph}$ Vertical, Aft on Truck Bed (Channel 1) 


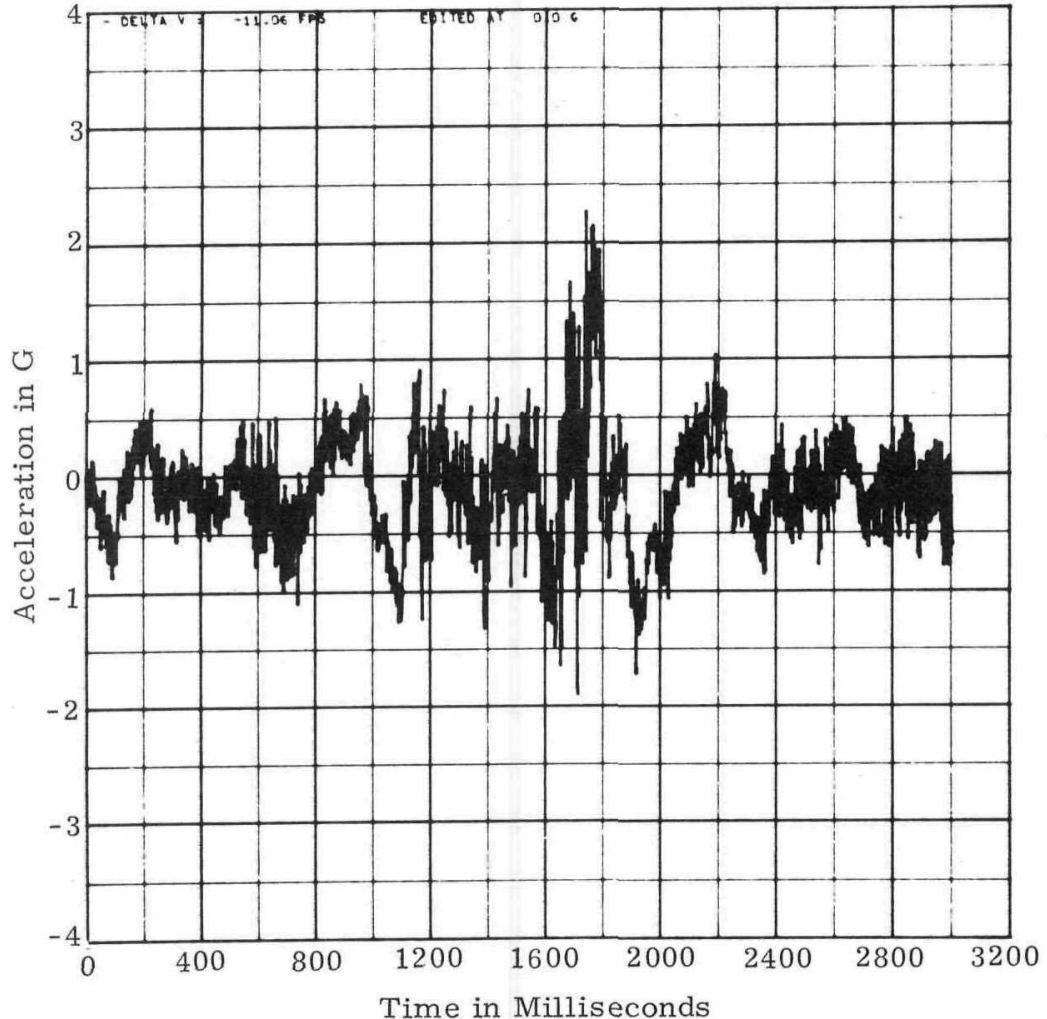

Figure B-14. Driving Across Cattle Guard at Slow Speed Vertical, Aft on Truck Bed (Channel 1)

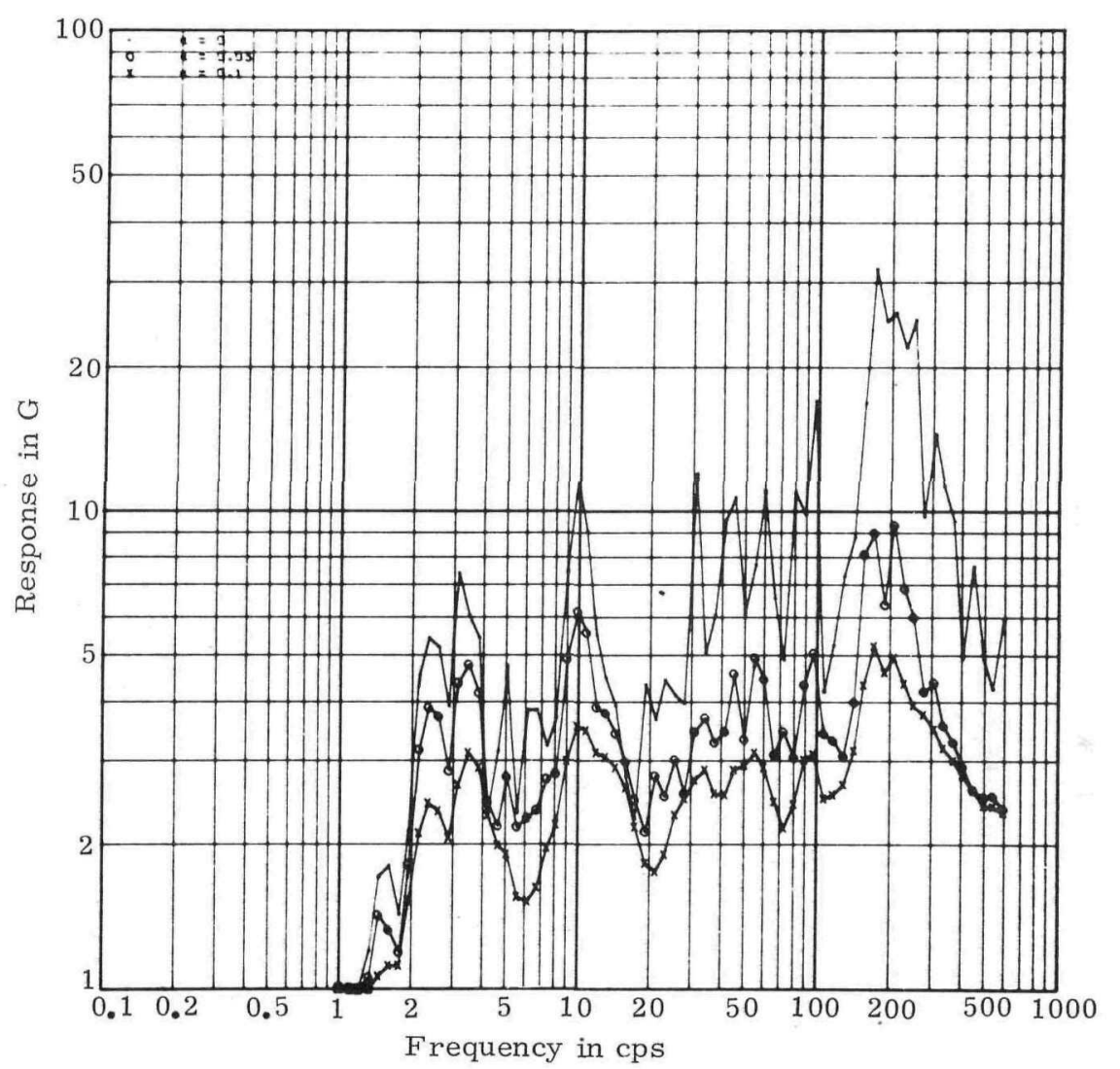

Figure B-15. Driving Across Cattle Guard at Slow Speed Vertical, Aft on Truck Bed (Channel 1) 


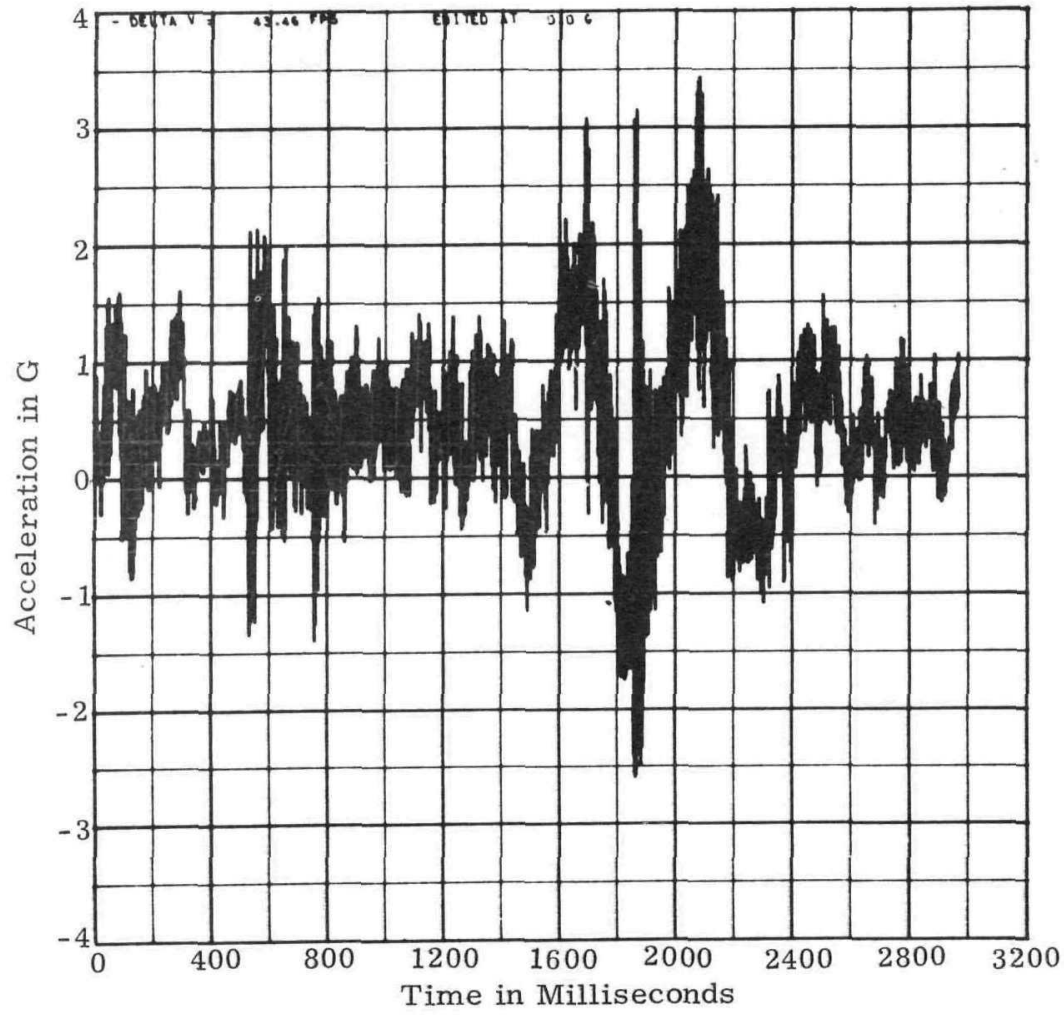

Figure B-16. Driving Across Pot Holes at Truck Stop Vertical, Truck Bed Aft (Channel 1)

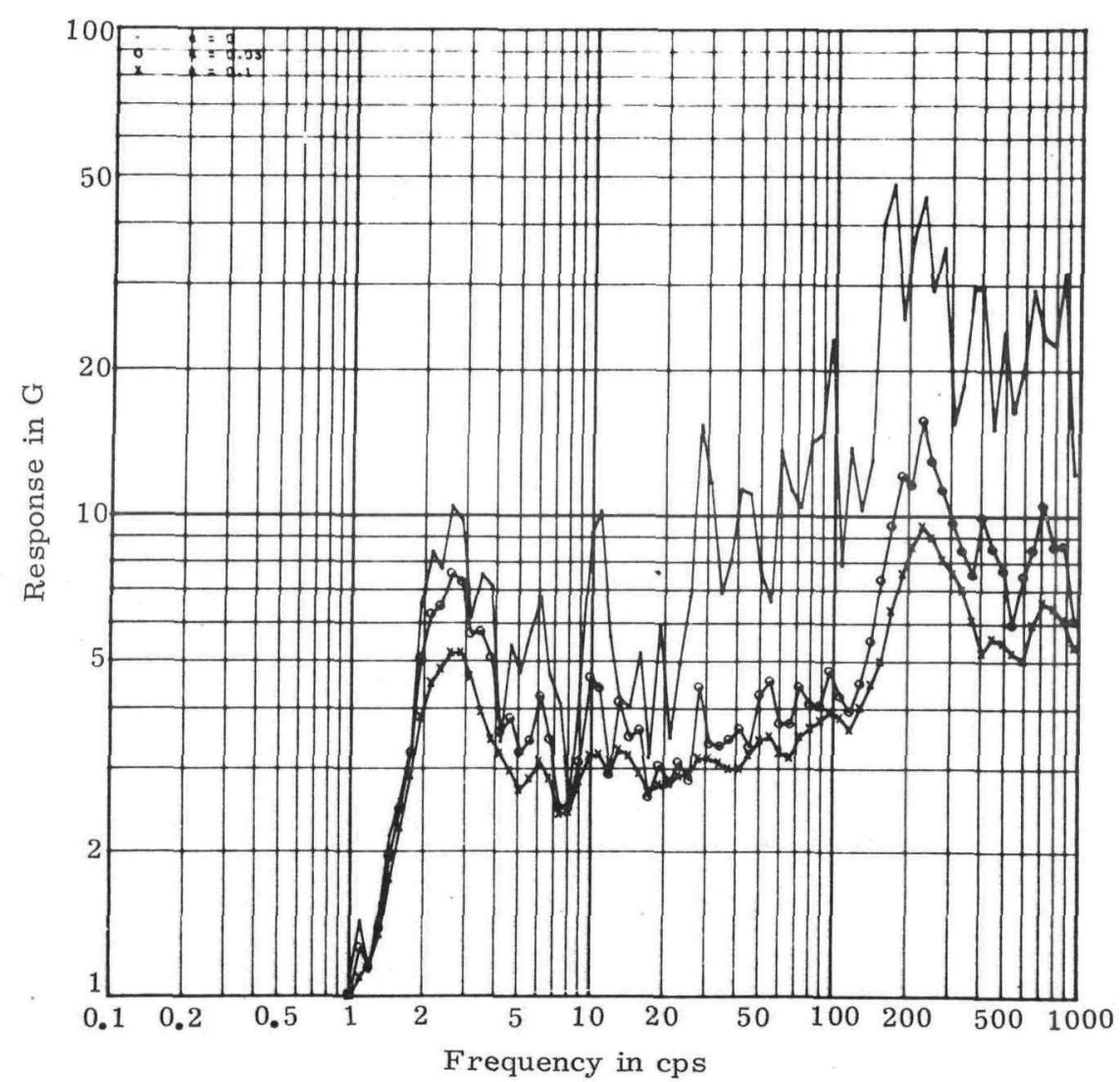

Figure B-17. Driving Across Potholes at Truck Stop Vertical, Aft on Truck Bed (Channel 1) 
DISTRIBUTION:

V. E. Isakson, Program Mgr., LEM

Beech Aircraft Corp.

P. O. Box 631

Boulder, Colorado

R. A. Meldrum

Office, Director of Transportation

Deputy Chief of Staff for Logistics

Dept. of the Army

Washington, D. C. 20545

Robert Kennedy

USA Transportation Engineering Agency

Ft. Eustis, Va. 23604

J. A. Lieberman

Div. of Reactor Development

AEC Headquarters

Washington, D. C. 20545

W. G. Belter

Sanitary Engineering Branch

Div. of Reactor Development

AEC Headquarters

Washington, D. C. 20545

J. A. Sisler

Traffic Management Branch

Div. of Construction

AEC Headquarters

Washington, D. C. 20545

John Langhaar

Atomic Energy Division

E. I. DuPont De Nemours

1007 Market Street

Wilmington, Delaware 19898

Steven H. Brown, Mgr.

Nuclear Service Dept.

National Lead Co.

Nuclear Metals Div.

111 Broadway

New York, N. Y.

10006

R. W. Johnson, Chief

Automotive Engineering Laboratory

U. S. Army Development and Proof Services

Aberdeen Proving Ground, Maryland

L. B. Shappert,

Union Carbide Nuclear Co.

Oak Ridge National Laboratory

Oak Ridge, Tennessee

37830

J. P. Salter

Royal Armament R \& D Establishment

Ministry of Defence

Ft. Halstead

Kent, England

J. E. Rice

Dept. $456 \mathrm{G}$

Goodyear Aerospace Corp.

1210 Massilon Rd.

Akron, Ohio

44306
U. S. Department of Agriculture

Forest Products Laboratory

P. O. Box 5130

Madison, Wisconsin 53705

Attn: W. O. Godshall

Packaging Research

Div. of Wood Engineering

Ministry of Technology

Aircraft Torpedo Development Unit

Helston, Cornwall, England

Attn: H. Robinson

General American Research Division

General American Transportation Corp.

7449 North Natchez Ave.

Miles, Illinois 60648

Attn: Fred Ostrem

W. Paulson

HIC Building - R - P\&VE SVE

George Marshall Space Flight Center

National Aeronautics \& Space Administration

Huntsville, Alabama 35812

Mechanical Information Division

Oak Ridge National Laboratory

Box X

Oak Ridge, Tennessee 37830

E. K. Snyder

Office of Weapons

Distribution \& Transportation Branch

AEC Albuquerque Operations

Sandia Base, New Mexico

87115

W. A. Gardner, 1500

D. M. Olson, 1510

B. E. Arthur, Jr., 1520

T. B. Lane, 1540

E. White, 7331, Attn: R. G. Hamilton

J. V. Otts, 7324

J. A. Mortley, 7334, Attn: F. R. Gustke

J. D. Patrick, 7335, Attn: T. B. Smart

H. R. Willis, 8146, Attn: C. A. Scott

E. A. Paxton, 8232

B. R. Allen, 3421

J. Shunny, 3411

R. S. Gillespie, 3413 (4)

C. H. Sproul, 3428-2 (10)

jk

\section{REPRODUCTION PERMISSION}

This report is not to be reproduced in whole or in part without written permission by the manager of the ariginating department. 